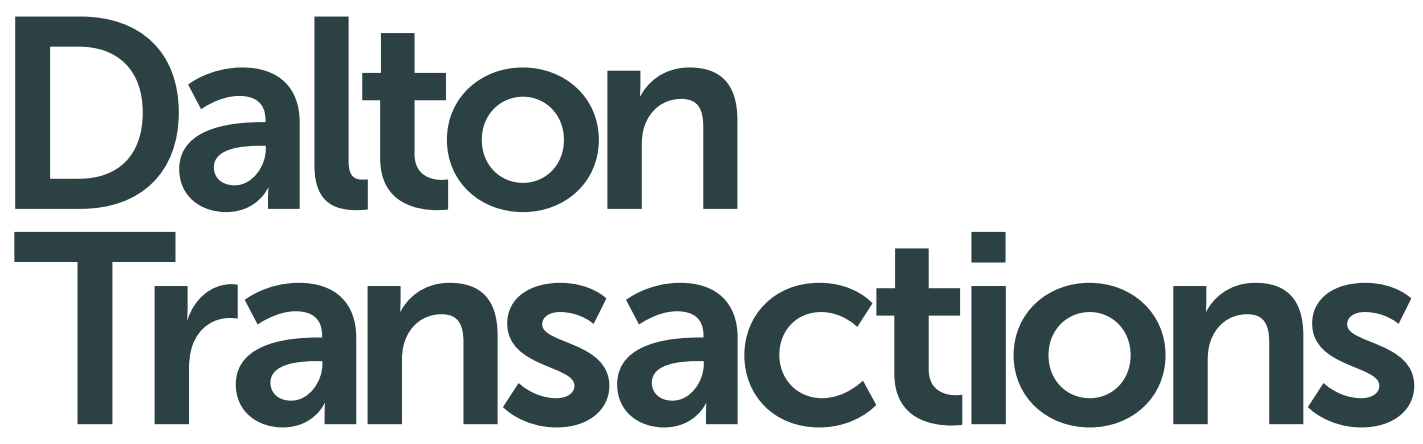

An international journal of inorganic chemistry www.rsc.org/dalton

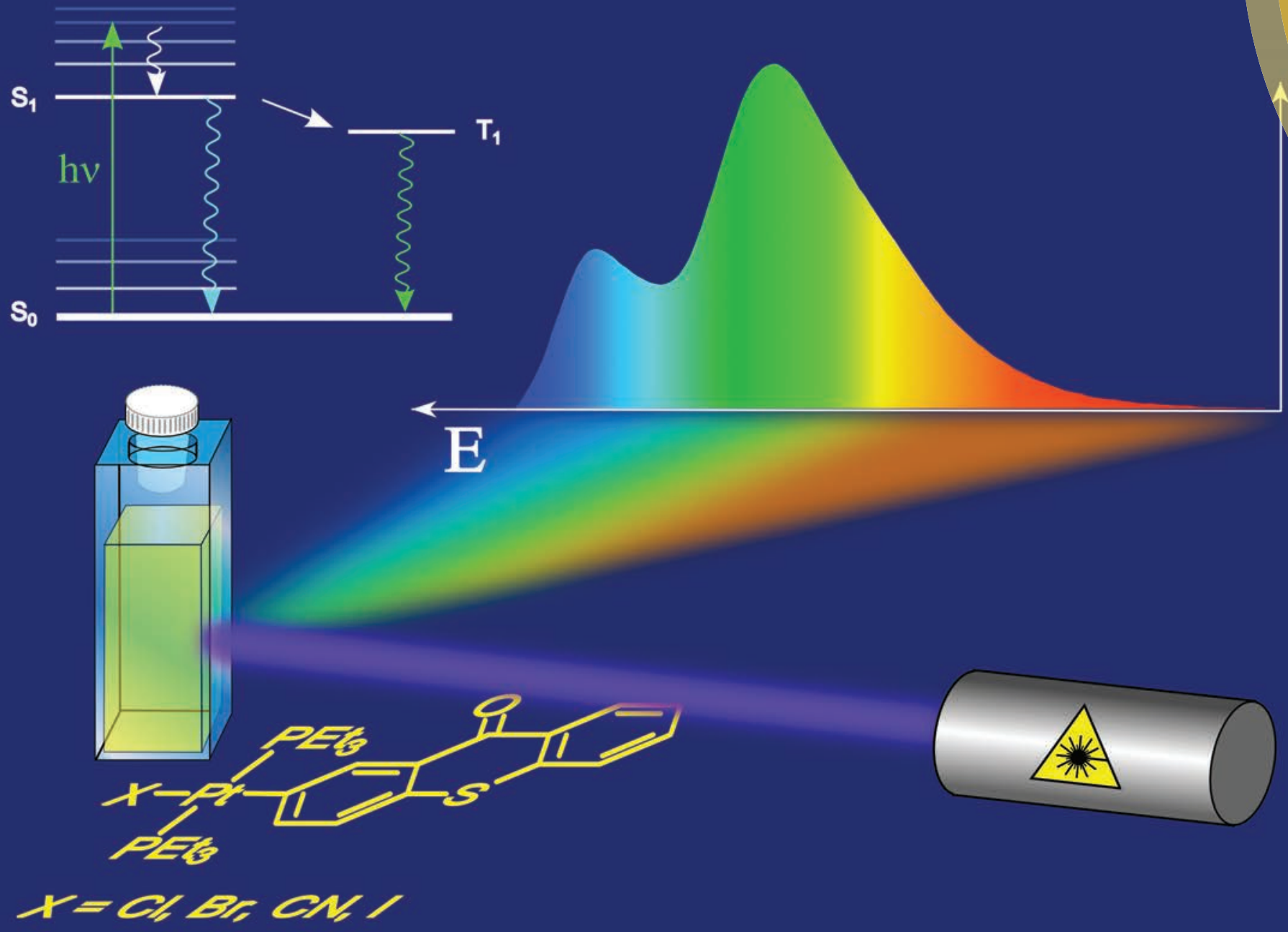




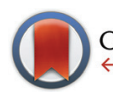

CrossMark

Cite this: Dalton Trans., 2015, 44 3974

Received 8th August 2014, Accepted 9th October 2014 DOI: $10.1039 / c 4 d t 02410 a$ www.rsc.org/dalton

\section{Dual ligand-based fluorescence and phosphorescence emission at room temperature from platinum thioxanthonyl complexes $\uparrow$}

\begin{abstract}
Fabian Geist, Andrej Jackel and Rainer F. Winter*
New square-planar platinum(॥) complexes of the type trans-[Pt $\left.\left(\mathrm{PEt}_{3}\right)_{2}(\mathrm{Tx})(\mathrm{X})\right](\mathrm{X}=\mathrm{Br}, \mathrm{Cl}, \mathrm{I}$ or $\mathrm{CN})$ bearing a $\sigma$-bonded thioxanthon-2-yl (Tx) ligand have been prepared and characterised by $\mathrm{X}$-ray crystallography, cyclic voltammetry, and by NMR and electronic absorption and luminescence spectroscopy. The ligand X hardly influences the electronic transitions, which indicates that the relevant molecular orbitals are largely confined to the Pt-Tx chromophore. In agreement with TD-DFT calculations the energetically lowest electronic transition is assigned as the Tx-centred $\pi \rightarrow \pi^{*} \mathrm{HOMO} \rightarrow$ LUMO excitation. All four complexes display dual emission from the $\sigma$-bonded Tx ligand at ca. $450 \mathrm{~nm}$ and at ca. $510 \mathrm{~nm}$, which are assigned as fluorescence originating from the ${ }^{1} \pi^{\star}$-state and as phosphorescence originating from the ${ }^{3} \pi^{\star}$-state, respectively. The phosphorescence quantum yield increases with increasing $\sigma$-donor strength of the ligand $\mathrm{X}$ and reaches a uniquely high value of $18.8 \%$ for the chlorido complex $\mathrm{Pt}-\mathrm{Cl}$. Switching-on of $\mathrm{Tx}$ phosphorescence emission by the $\operatorname{Pt}\left(\mathrm{PEt}_{3}\right)_{2}(\mathrm{X})$ fragment goes along with a reduction of the lifetime of the Tx triplet state from several $\mathrm{ms}$ in purely organic derivatives to ca. $2 \mu \mathrm{s}$ in the complexes.
\end{abstract}

\section{Introduction}

Within the last two decades, complexes of mainly the heavy transition metals have been the focus of intense research activities devoted to the fields of light emitting devices, ${ }^{1-6}$ bioimaging, ${ }^{5,7-9}$ sensing ${ }^{5,10-14}$ or sensitisation. ${ }^{15-17}$ One major advantage of metal complexes when compared to purely organic emitters is their ability to trigger long-lived phosphorescence at ambient temperature. Platinum, in particular, is a widely applied metal in this field because its heavy atom effect, which emanates from its large spin-orbit coupling constant, promotes high intersystem crossing (ISC) efficiencies. ${ }^{18}$ The utilisation of triplet emitters in organic light emitting devices can theoretically lead to a fourfold increase in efficiency compared to the $25 \%$ efficiency limit of organic fluorescent compounds. ${ }^{19,20}$

Fachbereich Chemie der Universität Konstanz, Universitätsstraße 10, D-78457 Konstanz, Germany.E-mail: rainer.winter@uni-konstanz.de $\dagger$ Electronic supplementary information (ESI) available: Depictions of the ${ }^{1} \mathrm{H},{ }^{13} \mathrm{C}$ $\left\{{ }^{1} \mathrm{H}\right\},{ }^{31} \mathrm{P}\left\{{ }^{1} \mathrm{H}\right\}$ and ${ }^{195} \mathrm{Pt}$ NMR spectra of the complexes; crystal and refinement data as well as ORTEPs and packing diagrams of complexes Pt-Cl and Pt-CN, graphical representations of exemplary cyclic voltammograms and electronic absorption and emission spectra, Tables with structure parameters for the optimised geometries of the complexes, energies and graphical representations of the crucial MOs of the complexes and TD-DFT calculated transitions. CCDC 1017997 (Pt-Cl) and 1017999 (Pt-CN). For ESI and crystallographic data in CIF or other electronic format see DOI: $10.1039 / \mathrm{c} 4 \mathrm{dt} 02410 \mathrm{a}$
In practice, the theoretical limit of unitary quantum efficiency is, however, rarely approached. One possible deactivation pathway for the excited states of square-planar platinum(II) complexes involves distortion towards a more tetrahedral geometry by a twisting of the plane of two donors with respect to that of the other two (the so-called $D_{2 \mathrm{~d}}$ distortion). This pathway is particularly relevant for complexes with only mono- or bidentate ligands. The main reason for low quantum yields and hence increased deactivation rates of emissive states is, however, the thermal activation of non-emissive excited metal d-states which are energetically above the emissive triplet states. A ligand field-induced destabilisation of these excited metal d-states will thus lead to increased quantum yields. ${ }^{18,21}$ Much effort has therefore been directed to introducing strong-field ligands into the coordination sphere of such complexes. Prominent examples are cyclometalating ligands such as the ubiquitous $N, C$ - or $N, N, C$-chelating arylpyridines or -bipyridines, ${ }^{18,22-39}$ simple or cyclometalating carbenes and bis(carbenes), ${ }^{3,6,36,37,40-45}$ or $\sigma$-bonded alkynyl ligands. ${ }^{46-51}$ Particularly abundant are trans-bis(alkynyl)bis(trialkylphosphine)platinum(II) complexes trans-Pt $(\mathrm{C} \equiv \mathrm{CR})_{2}\left(\mathrm{PR}_{3}\right)_{2} \cdot{ }^{52,53}$ Such complexes have, for example been used as constituents of luminescent coordination oligomers and polymers featuring platinum atoms in the conjugated main chain $^{54-63}$ or for two-photon absorption (TPA). ${ }^{64}$ Other representatives have organic dyes as the substituents at the alkynyl ligands. These complexes exhibit intense ligand-based 
$\pi \rightarrow \pi^{*}$-transitions and usually emit from ligand-centred $\pi^{*}$-states with moderate fluorescence or phosphorescence quantum yields in fluid solution at ambient temperature. ${ }^{49,53,65-69}$ Again, ISC to a ligand-based excited triplet state is triggered by the large heavy-atom effect of the $\mathrm{Pt}$ (II) coordination centre. In rare cases, where the excited states are mainly localised at those ligands and spin-orbit coupling is attenuated by small Pt (5d) contribution to the relevant frontier molecular orbitals, dual emission from the ${ }^{1} \mathrm{~L}$ and ${ }^{3} \mathrm{~L}$ or ${ }^{3} \mathrm{MLCT}$ excited states has been observed. ${ }^{70-72}$

$\sigma$-Bonded aryl ligands exert an even stronger ligand-field splitting than alkynyl ones. Despite the large and rapidly growing number of complexes featuring the above-mentioned cyclometalating arylpyridine $^{24}$ or arylphosphine ${ }^{73}$ ligands, there are relatively few examples of luminescent Pt(II) complexes possessing simple, non-chelating $\sigma$-bonded aryl ligands. ${ }^{74-76}$ Most of these complexes show exclusively aryl ligand-centred emission from the ${ }^{1} \pi^{*}$-state with lifetimes in the ns regime ${ }^{77}$ or emit with low quantum yields from the ${ }^{3} \pi^{*}$-state. ${ }^{78}$ Notable exceptions are trans-Pt $\left(\mathrm{PEt}_{3}\right)_{2} \mathrm{Br}$-complexes featuring the anthracen-9-yl ligand or some of its brominated derivatives of Sharp et al., which are formed by oxidative addition of the respective 9-bromoanthracenes to $\mathrm{Pt}\left(\mathrm{PEt}_{3}\right)_{4}$. These complexes were found to undergo P-type delayed fluorescence with quantum yields of close to $90 \%$ and lifetimes of a few microseconds. ${ }^{79}$ This finding clearly indicates that a triplet state is involved in the radiative deactivation process of the initially generated excited state and that the $\mathrm{Pt}\left(\mathrm{PEt}_{3}\right)_{2} \mathrm{Br}$ fragment is capable of strongly accelerating the ISC rate from the ${ }^{1} \pi^{*}$ - to the ${ }^{3} \pi^{*}$-state. In contrast, attaching the $\mathrm{Pt}\left(\mathrm{PEt}_{3}\right)_{2} \mathrm{Br}-$ fragment to the 3-position of perylene or the 9-position of perylene-3,4-dicarboximide (PMI) does not lead to the expected fast ISC, but promotes ligand-based fluorescence with quantum yields of 70 or $30 \%$, respectively. Further modification of these complexes by substituting the bromido ligand by either cyanido, thiocyanato or neutral ligands such as 4-methylpyridine or ${ }^{t}$ butylisocyanide hardly affects the quantum yields in the case of the perylene complexes (70-80\%) whereas those for the PMI analogues were found to vary from $30 \%$ for the neutral complexes to $78 \%$ for the cationic isocyanide derivative. ${ }^{80}$

The favourable photophysical properties of thioxanthones have prompted us to prepare and to investigate the complexes trans $-\mathrm{Pt}\left(\mathrm{PEt}_{3}\right)_{2}(\mathrm{X})$ (thioxanthonyl) $(\mathrm{X}=\mathrm{Cl}, \mathrm{Br}$, I or $\mathrm{CN})$ bearing the $\sigma$-bonded thioxanthon-2-yl ligand. The ready formation of the ${ }^{3} \pi \pi^{*}$ - and ${ }^{3} n \pi^{*}$-states of aromatic carbonyl compounds after photoexcitation into the ${ }^{1} \pi \rightarrow \pi^{*}$ - and ${ }^{1} \mathrm{n} \rightarrow \pi^{*}$-bands ${ }^{81-84}$ renders thioxanthone derivatives useful sensitisers ${ }^{85,86}$ or initiators for radical photopolymerisations of olefins. ${ }^{87-93}$ The excited states of thioxanthones involve two singlet states $S_{1}$ $\left({ }^{1} \pi \pi^{*}\right)$ and $S_{2}\left({ }^{1} n \pi^{*}\right)$ and two corresponding triplet states $T_{1}$ $\left({ }^{3} \pi \pi^{*}\right)$ and $T_{2}\left({ }^{3} n \pi^{*}\right)$, which readily equilibrate (Fig. 1). ${ }^{94,95}$ Apolar solvents decrease the energy gap between the two singlet states due to either a stabilisation of the ${ }^{1} n \pi^{*}$-state or a destabilisation of the ${ }^{1} \pi \pi^{*}$-state. The energetical proximity of these two states leads to strong vibronic coupling between

\section{purely organic Tx}

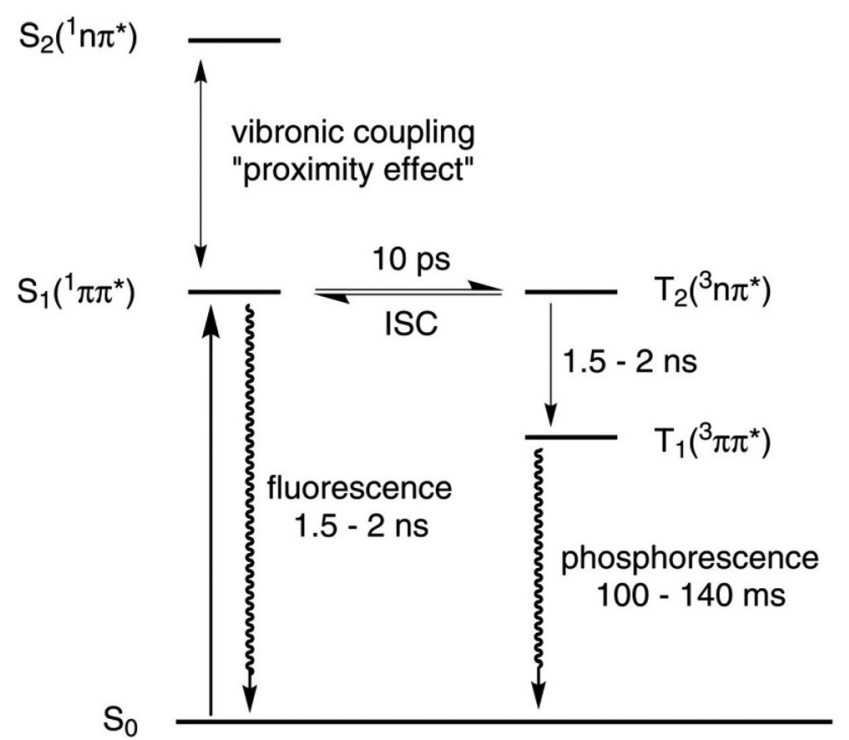

Fig. 1 Qualitative Jablonski diagram illustrating the photophysical behaviour of thioxanthones.

them. This so-called proximity effect is responsible for increasing the non-radiative deactivation rate as well as increasing the fluorescence energy. Furthermore, this effect also lowers the quantum yield for triplet formation. ${ }^{96}$ Two principal pathways for ISC in thioxanthones were found: (a) a very fast direct mechanism leading from the ${ }^{1} \mathrm{n} \pi^{*}$ - to the ${ }^{3} \pi \pi^{*}$-state and (b) a slow indirect mechanism leading from the ${ }^{1} \pi \pi^{*}$ - to the ${ }^{3} \pi \pi^{*}$ state with the ${ }^{3} n \pi^{*}$-state as the intermediate. ${ }^{95,97}$ Although ISC of thioxanthones is rather efficient, they mainly emit through fluorescence because the $T_{1}$ state with a lifetime of 100 to $140 \mathrm{~ms}$ is so long-lived that radiationless deactivation pathways become dominant. Phosphorescence is usually observed in glassy matrices at $77 \mathrm{~K}$ but only rarely in fluid solution with much lower quantum yields. ${ }^{89,90,97}$ It was therefore our hope that attachment of the $\left\{\mathrm{Pt}\left(\mathrm{PEt}_{3}\right)_{2} \mathrm{X}\right\}$-fragment to the thioxanthonyl core should further increase the ISC rate and hence open a pathway for radiative decay of the $T_{1}$ to the $S_{0}$ state. We here report our findings on the complexes $\mathbf{P t}-\mathbf{C l}$ to $\mathbf{P t}-\mathbf{C N}$ of Scheme 1, including the observation of dual fluorescence and phosphorescence emissions from the thioxanthone chromophore.

\section{Results and discussion}

\section{Synthesis}

Oxidative addition of 2-bromo-9H-thioxanthen-9-one (Br-Tx) to $\mathrm{Pt}\left(\mathrm{PEt}_{3}\right)_{4}$ gave the trans complex $\mathbf{P t}-\mathbf{B r}$ (Scheme 1). Monitoring the progress of the reaction via ${ }^{1} \mathrm{H}$ and ${ }^{31} \mathrm{P}$ NMR spectroscopy provided no evidence for initial formation of the kinetically favoured cis-isomer at room temperature. Subsequent abstraction of the bromido ligand of $\mathbf{P t}-\mathbf{B r}$ with $\mathrm{AgBF}_{4}$ in methanol 

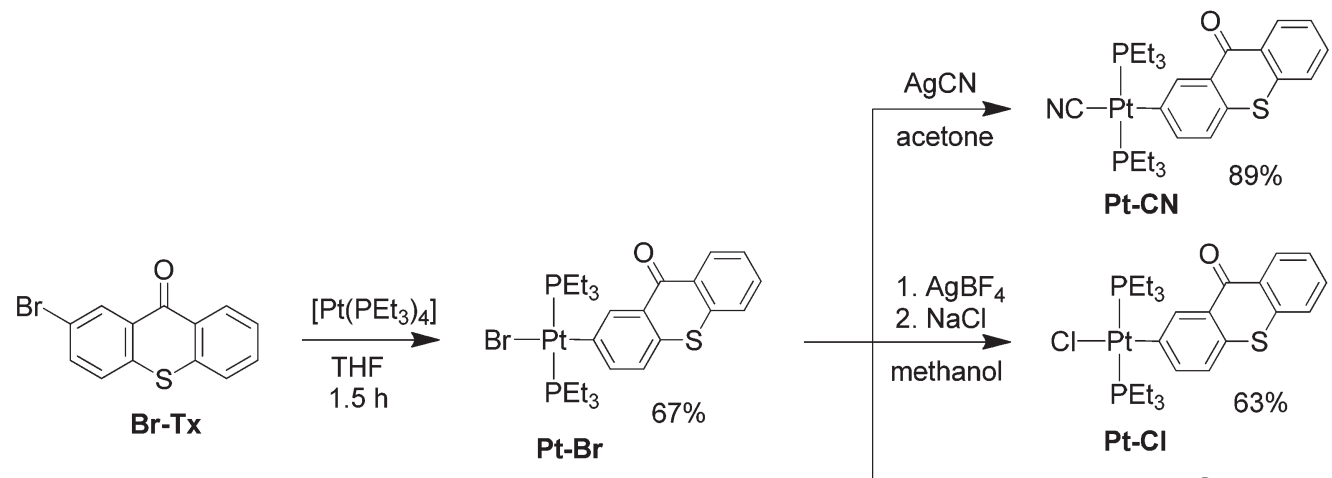

.

and addition of $\mathrm{NaCl}$ or NaI gave the halogenido complexes Pt-Cl and Pt-I, respectively. The analogous cyanido complex Pt-CN was similarly obtained by treatment of $\mathbf{P t - B r}$ with $\mathrm{AgCN}$. All complexes were purified by recrystallisation from toluene or acetone and were obtained in yields of 63 to $89 \%$. We note that all trans-XPt $\left(\mathrm{PEt}_{3}\right)_{2}(\mathrm{Tx})$ complexes $(\mathrm{X}=\mathrm{Br}, \mathrm{Cl}$, I or $\mathrm{CN})$ are much more soluble in polar organic solvents than Br-Tx.

Attempts to purify Pt-Br by chromatography on basic alumina with $\mathrm{CH}_{2} \mathrm{Cl}_{2}$ as the eluent resulted in halide exchange, putatively via oxidative addition of $\mathrm{CH}_{2} \mathrm{Cl}_{2}$ and reductive elimination of $\mathrm{CH}_{2} \mathrm{BrCl}$ to form complex $\mathbf{P t}-\mathrm{Cl}^{.}{ }^{98,99} \mathrm{~A}$ second possible reaction sequence is the bromide abstraction by alumina resulting in a cationic complex that subsequently reacts with $\mathrm{CH}_{2} \mathrm{Cl}_{2}$ to form Pt-Cl. When basic alumina was added to $\mathrm{CD}_{2} \mathrm{Cl}_{2}$ solutions of $\mathbf{P t}-\mathbf{B r}$ that were kept in the dark, exchange of the bromido by the chlorido ligand was much slower and occurred only over a period of two weeks as probed by ${ }^{31} \mathrm{P}$ NMR spectroscopy.

\section{Single-crystal X-ray diffraction studies of Pt-Cl and Pt-CN}

Slow evaporation of concentrated dichloromethane solutions of Pt-I, Pt-CN, Pt-Cl and Pt-Br gave single crystals in each case. While data sets of Pt-I and Pt-Br were unsatisfactory, needle shaped single-crystals of $\mathbf{P t - C l}$ and $\mathbf{P t}-\mathbf{C N}$ provided data sets of sufficient quality to allow for successful refinement. The ORTEPs of the structures are shown in Fig. 2a for Pt-Cl and in Fig. 2b for Pt-CN while details of the crystallographic measurement, data collection and refinement are provided as Tables $\mathrm{S} 1$ and $\mathrm{S} 3$ of the ESI. $\dagger$ Complex Pt-Cl crystallises in the monoclinic space group $P 2_{1} / c$ and Pt-CN in the triclinic space group $P \overline{1}$. The Pt atoms of both complexes are in almost ideal square-planar coordination environments with bond angles of $86.67(4)$ to $93.52(15)^{\circ}$ and angle sums of
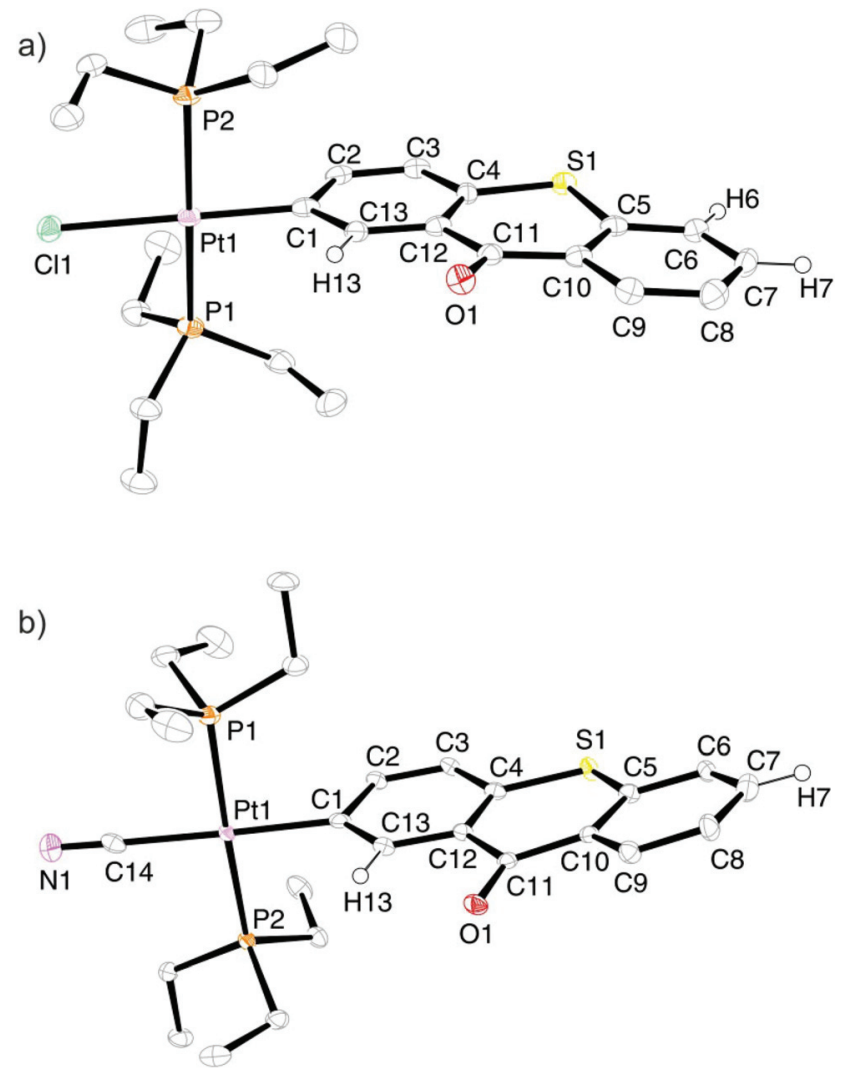

Fig. 2 ORTEPs of Pt-Cl (a) and Pt-CN (b); ellipsoids are drawn at a $40 \%$ probability level. $\mathrm{H}$ atoms are omitted for clarity except for $\mathrm{H} 6, \mathrm{H} 7$ and $\mathrm{H} 13$ of $\mathrm{Pt}-\mathrm{Cl}$ and $\mathrm{H} 7$ and $\mathrm{H} 13$ of $\mathrm{Pt}-\mathrm{CN}$. Selected bond lengths [Å] and angles [ ${ }^{\circ}$ ] of Pt-Cl: Cl1-Pt1 2.4001(13), P1-Pt1 2.3084(11), P2-Pt1 2.3058(11), C1-Pt1 2.010(5), P1-Pt1-P2 175.07(4), C1-Pt1-Cl1 178.98(13), P1-Pt1-Cl1 86.67(4), C1-Pt1-P1 92.63(10), C1-Pt1-P2 87.42(10), P2-Pt1-Cl1 93.21(4); Pt-CN: C14-Pt1 2.048(6), P1-Pt1 2.3098(14), P2-Pt1 2.3049(13), C1-Pt1 2.052(5), P1-Pt1-P2 175.39(5), C1-Pt1-C14 178.6(2), P1-Pt1-C14 88.16(15), C1-Pt1-P1 90.39(14), C1-Pt1-P2 87.92(14), P2-Pt1-C14 93.52(15). 
a)

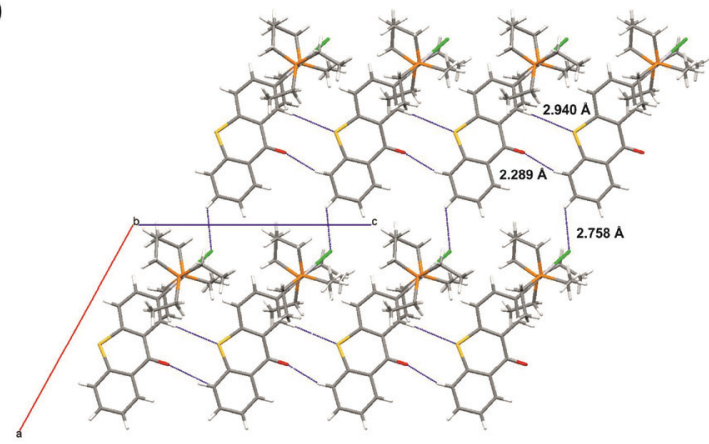

c)

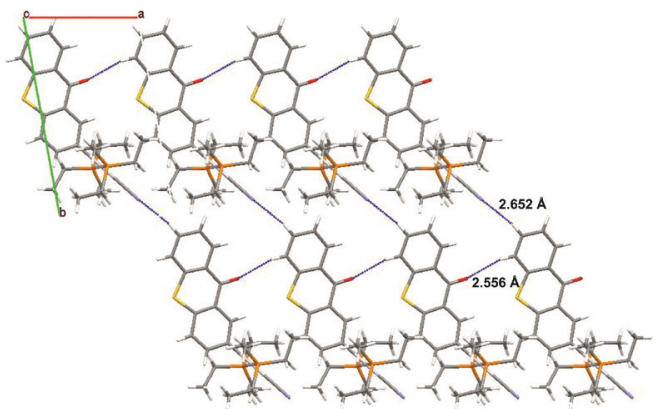

b)

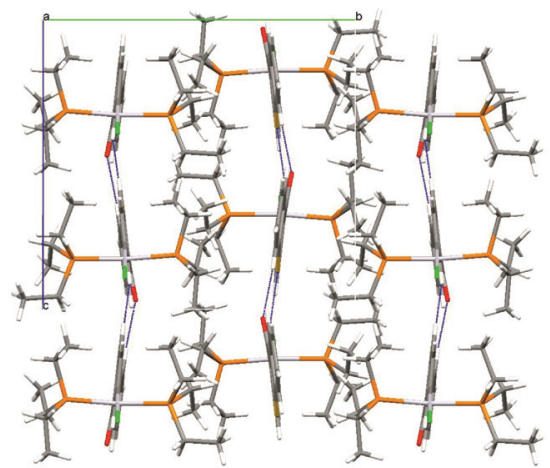

d)

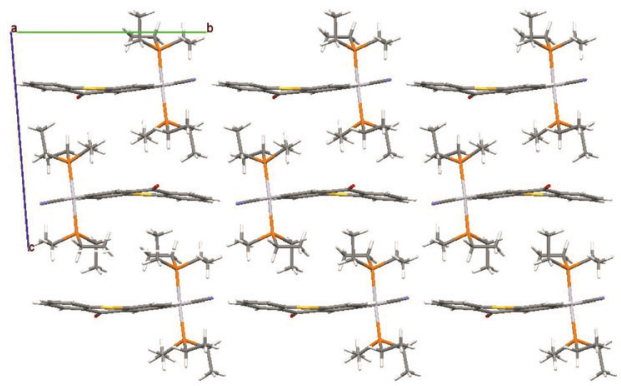

Fig. 3 Molecule packing of Pt-Cl and Pt-CN in the crystal. View along the crystallographic $b$ axis (a) and the $a$ axis (b) of Pt-Cl and along the crystallographic $c$ axis (c) and the a axis (d) of Pt-CN.

359.9 and 360.0, respectively (Fig. 2 and 3). While the X-Pt1C1 (X = Cl1 of Pt-Cl or C14 of Pt-CN) bond angles of $178.98(13)$ and $178.6(2)^{\circ}$ match the expected $180^{\circ}$ of a squareplanar coordination sphere almost perfectly, the P1-Pt1-P2 bond angles of $175.07(4)^{\circ}$ for Pt-Cl and 175.39(5) ${ }^{\circ}$ for Pt-CN differ by about $5^{\circ}$ from the ideal value. This is the result of a slight bending of the $\mathrm{PEt}_{3}$ ligands toward the side of the intracyclic $\mathrm{S}$ atom of the thioxanthonyl ligand. The thioxanthonyl ligand is not exactly planar with some puckering about the S1-C11-O1 vector, which amounts to $5.0^{\circ}$ for $\mathbf{P t}-\mathbf{C l}$ and to $11.8^{\circ}$ for Pt-CN. The best plane through the Tx ligand of the complexes adopts a nearly orthogonal orientation to the platinum coordination plane as is seen by the angles of $85.0^{\circ}$ for Pt-Cl and $86.5^{\circ}$ for $\mathbf{P t}-\mathbf{C N}$ formed between the metal bonded aryl ring of that ligand and the best plane through atoms Pt1, $\mathrm{P} 1, \mathrm{P} 2, \mathrm{C} 1$ and $\mathrm{Cl} 1$ or $\mathrm{C} 14$ of the cyanido ligand. The Pt-CN axis of complex Pt-CN is tilted by $1.2^{\circ}$ with respect to the plane formed by atoms $\mathrm{Pt} 1, \mathrm{C} 14, \mathrm{P} 1, \mathrm{P} 2$ and $\mathrm{C} 1$. Pt-C1 bond lengths of 2.010(5) $\AA$ for $\mathbf{P t}-\mathbf{C l}$ and of 2.052(5) $\AA$ for $\mathbf{P t}-\mathbf{C N}$ reflect the trans-effect of the (pseudo)halogenido ligand.

In the crystal, individual molecules of Pt-Cl associate to 1D chains along the crystallographic $c$ axis by a total of four hydrogen bonds $\mathrm{O} 1-\mathrm{H} 6 \mathrm{a}$ and $\mathrm{S} 1-\mathrm{H} 13 \mathrm{a}$ with $\mathrm{O} \cdots \mathrm{H}$ and $\mathrm{S} \cdots \mathrm{H}$ distances of 2.289 and $2.940 \AA$ for $\mathbf{P t}-\mathbf{C l}$, respectively, which is 43 and $19 \mathrm{pm}$ shorter than the sum of the van der Waals radii (see Fig. 3a). In contrast, individual molecules of Pt-CN form two hydrogen bonds $\mathrm{O} 1-\mathrm{H} 13 \mathrm{a}$ along the crystallographic $a$ axis with a distance of $2.556 \AA, 16$ pm shorter than the sum of the van der Waals radii, Fig. 3c. Within each chain of Pt-Cl, neighbouring molecules are tilted with respect to each other by $13.3^{\circ}$ with respect to their thioxanthone planes in a slight zigzag pattern (Fig. 3b). Individual chains of both complexes are further connected through hydrogen bonds between H7a and the chlorido or cyanido ligand with $\mathrm{H} \cdots \mathrm{X}$ distances of 2.758 or $2.652 \AA$, respectively. For Pt-CN, these chains are offset along the $b c$ plane and arrange in a brick wall-type fashion (see Fig. 3d).

Individual molecules of these complexes thus form twodimensional sheet structures within the $a c$ or $a b$ planes, respectively. Individual chains of $\mathbf{P t - C l}$ are further offset along the $a c$ plane whereas those of $\mathbf{P t - C N}$ are offset along the $b c$ plane. Each thioxanthonyl ligand of the complexes is surrounded by two phosphine ligands belonging to neighbouring chains, one above and one below the thioxanthone plane. Thus no Pt...Pt or $\pi$-stacking interactions are observed in the solid state. This may contribute to the much higher solubility of the complexes when compared to the free ligand.

\section{NMR spectroscopic characterisation}

The ${ }^{31} \mathrm{P}\left\{{ }^{1} \mathrm{H}\right\}$ NMR spectra of Pt-Cl, Pt-Br, Pt-CN and Pt-I all reveal just one sharp singlet flanked by ${ }^{195} \mathrm{Pt}$ satellites (natural abundance $33.8 \%$; Fig. 4a) which testifies to the trans arrangement of the phosphine ligands. The chemical shifts (Table 1) increase in the order $\mathrm{I}<\mathrm{CN}<\mathrm{Br}<\mathrm{Cl}$. For the halogenido ligands the ordering parallels decreasing $\sigma$-basicity against platinum, while the cyanido ligand one sticks out because of 
a)

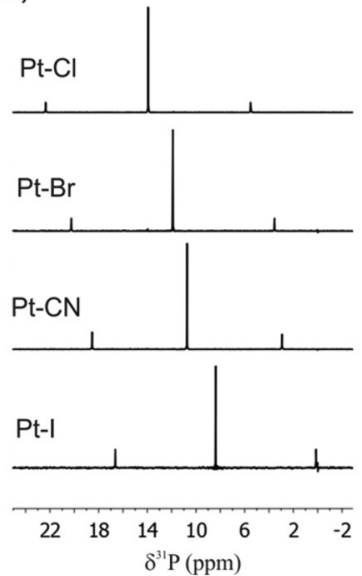

b)
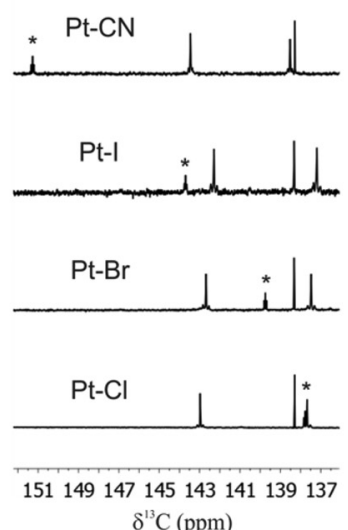

c)
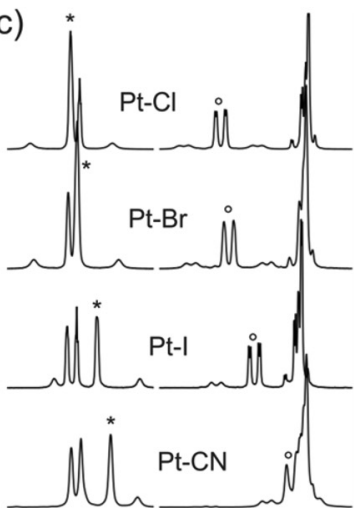

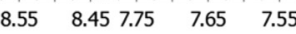

$\delta^{\prime} \mathrm{H}(\mathrm{ppm})$

Fig. 4 (a) ${ }^{31} \mathrm{P}\left\{{ }^{1} \mathrm{H}\right\} N M R$ spectra of $\mathrm{Pt}-\mathrm{Cl}, \mathrm{Pt}-\mathrm{Br}, \mathrm{Pt}-\mathrm{CN}$ and $\mathrm{Pt}-\mathrm{I}$. (b) ${ }^{13} \mathrm{C}\left\{{ }^{1} \mathrm{H}\right\}$ NMR spectra of $\mathrm{Pt}-\mathrm{Cl}, \mathrm{Pt}-\mathrm{Br}$, $\mathrm{Pt}-\mathrm{CN}$ and $\mathrm{Pt}-\mathrm{I}$. The asterisks indicate the signal of the platinum bonded carbon atom $\mathrm{C}$. (c) ${ }^{1} \mathrm{H}$ NMR spectra $\mathrm{Pt}-\mathrm{Cl}, \mathrm{Pt}-\mathrm{Br}, \mathrm{Pt}-\mathrm{CN}$ and $\mathrm{Pt}-\mathrm{I}$ in the spectral region of the ortho protons of the Tx ligand. The asterisks mark the resonance signal atom $\mathrm{H} 13$ and the circles that of $\mathrm{H} 2$.

Table $1 \quad{ }^{195} \mathrm{Pt}, \delta{ }^{31} \mathrm{P}, \delta^{13} \mathrm{C}$ and $\delta{ }^{1} \mathrm{H}$ chemical shifts of $\mathrm{Pt}-\mathrm{Br}, \mathrm{Pt}-\mathrm{Cl}, \mathrm{Pt}-\mathrm{I}$ and $\mathrm{Pt}-\mathrm{CN}$ with selected coupling constants; n.d. = not determined

\begin{tabular}{|c|c|c|c|c|c|}
\hline & $\delta^{195} \mathrm{Pt}$ & $\begin{array}{l}\delta^{31} \mathrm{P}[\mathrm{ppm}] / \\
{ }^{1} J_{\mathrm{Pt}-\mathrm{P}}[\mathrm{Hz}]\end{array}$ & $\begin{array}{l}\delta^{13} \mathrm{C}, \mathrm{C} 1[\mathrm{ppm}] / \\
{ }^{1} J_{\mathrm{Pt}-\mathrm{C}}[\mathrm{Hz}] /{ }^{2} J_{\mathrm{P}-\mathrm{C}}[\mathrm{Hz}]\end{array}$ & $\begin{array}{l}\delta^{1} \mathrm{H}, \mathrm{H} 13[\mathrm{ppm}] / \\
{ }^{3} J_{\mathrm{Pt}-\mathrm{H}}[\mathrm{Hz}]\end{array}$ & $\begin{array}{l}\delta^{1} \mathrm{H}, \mathrm{H} 2[\mathrm{ppm}] / \\
{ }^{3} J_{\mathrm{Pt}-\mathrm{H}}[\mathrm{Hz}]\end{array}$ \\
\hline Pt-Cl & -4257 & $13.93 / 2725$ & $137.8 / 960 / 9.2$ & $8.55 / 69.2$ & $7.71 / 61.9$ \\
\hline Pt-CN & -4674 & $10.73 / 2524$ & 151.3/n.d./10.5 & $8.50 / 45.1$ & $7.61 / 40.9$ \\
\hline Pt-I & -4602 & $8.39 / 2668$ & 143.7/n.d./8.8 & $8.52 / 71.9$ & $7.66 / 64.0$ \\
\hline
\end{tabular}

its strong $\pi$-accepting capability. ${ }^{100}$ Observed coupling constants range from $2524 \mathrm{~Hz}$ for $\mathbf{P t}-\mathbf{C N}$ to $2725 \mathrm{~Hz}$ for $\mathbf{P t}-\mathbf{C l}$ and are unexceptional when compared to other complexes trans$\mathrm{Pt}(\sigma$-aryl $)\left(\mathrm{PEt}_{3}\right)_{2}(\mathrm{X}) \cdot{ }^{79,80,100}$ The ${ }^{1} J_{\mathrm{Pt}-\mathrm{P}}$ coupling constants reflect the s character of the Pt-P and Pt-X $\sigma$-bond ${ }^{101,102}$ and follow the order $\mathrm{CN}<\mathrm{I}<\mathrm{Br}<\mathrm{Cl}$. The ${ }^{195} \mathrm{Pt}$ signal of every complex is split into a triplet by coupling to the two equivalent phosphorus nuclei and the shift follows a similar trend to the ${ }^{31} \mathrm{P}$ chemical shift with the exception of complex Pt-CN, whose ${ }^{195} \mathrm{Pt}$ resonance appears at higher field than that of $\mathbf{P t}-\mathbf{I}$.

The ${ }^{13} \mathrm{C}$ NMR signal of the metal-bonded $\mathrm{C} 1$ atom of every complex is also split into a triplet due to coupling to the two cis positioned phosphorus nuclei with ${ }^{2} J_{\mathrm{P}-\mathrm{C}}$ coupling constants ranging from $8.8 \mathrm{~Hz}$ for Pt-I to $10.5 \mathrm{~Hz}$ for $\mathbf{P t}-\mathbf{C N}$. The chemical shift of the $\mathrm{C} 1$ atom clearly depends on the (pseudo)halogenido ligand (Fig. 4b, Table 1 and Experimental section). From the data in Table 1 and Fig. $4 \mathrm{~b}$ one can infer that the resonance signal of carbon atom C1 dramatically shifts to lower field as the back bonding ability of the trans disposed ligand increases. ${ }^{195} \mathrm{Pt}$ satellites of the $\mathrm{C} 1{ }^{13} \mathrm{C}$ resonance signal of 960 and $972 \mathrm{~Hz}$, respectively, were detected for complexes Pt-Cl and Pt-Br but not for the other two complexes because of the lower signal to noise ratio of the experimental spectra. For the two complexes $\mathbf{P t}-\mathbf{C l}$ and $\mathbf{P t}-\mathbf{B r}$ the ${ }^{1} J_{\mathrm{Pt}-\mathrm{C} 1}$ coupling constants have an inverse ordering to the ${ }^{1} J_{\mathrm{Pt}-\mathrm{P}}$ coupling constants, which indicates that these two kinds of ligands compete for the $6 \mathrm{~s}$ electron density at the Pt atom. The chemical shifts of all other carbon atoms remain almost unchanged along this series. The coupling constants ${ }^{3} J_{\mathrm{Pt}-\mathrm{H} 2}$ and ${ }^{3} J_{\mathrm{Pt}-\mathrm{H} 13}$ to the Tx protons in the ortho positions to the platinum atom amount to ca. $70 \mathrm{~Hz}$ and $63 \mathrm{~Hz}$, respectively, for the halogenido complexes and to $c a .45$ or $41 \mathrm{~Hz}$ for the cyanido complex and follow the ordering of the trans-influence of the ligand $\mathrm{X}(\mathrm{CN} \ll \mathrm{Cl}<\mathrm{Br}<\mathrm{I})$.

\section{Electronic absorption spectroscopy}

Fig. 5a depicts the room temperature electronic absorption spectra of the four complexes and of the free ligand $\mathbf{B r}-\mathbf{T x}$ in $\mathrm{CH}_{2} \mathrm{Cl}_{2}$ while relevant data are collected in Table 2. Like for the $\mathbf{B r}-\mathbf{T x}$ precursor, the spectra of the platinum complexes feature prominent UV absorption with extinction coefficients $\varepsilon$ of the order of $4 \times 10^{4}$ and a much weaker one $\left(\varepsilon \approx 5 \times 10^{3}\right)$ at about $400 \mathrm{~nm}$ which is responsible for the yellow colour of $\mathbf{B r}-$ Tx and the complexes. Attachment of the $\left\{(\mathrm{X}) \mathrm{Pt}\left(\mathrm{PEt}_{3}\right)_{2}\right\}$-fragment $(\mathrm{X}=\mathrm{Br}, \mathrm{Cl}$, I or $\mathrm{CN})$ to the thioxanthone core increases the intensity of the UV bands and red shifts the low energy band by $644 \mathrm{~cm}^{-1}$ for the cyanido complex and by $c a$. $895 \mathrm{~cm}^{-1}$ for the halogenido complexes. Donor substitution of thioxanthones at the 2-position generally red shifts the low energy band owing to a destabilisation of the highest occupied molecular orbital (HOMO). Shifts are in the range of $1740 \mathrm{~cm}^{-1}$ (in acetonitrile) for alkoxy ${ }^{88}$ and of $410 \mathrm{~cm}^{-1}$ (in benzene) for alkyl ${ }^{87}$ substituents. Thus, in a first approximation, the $\left\{(\mathrm{X}) \mathrm{Pt}\left(\mathrm{PEt}_{3}\right)_{2}\right\}$-fragment seems to act as a moderate 
a)

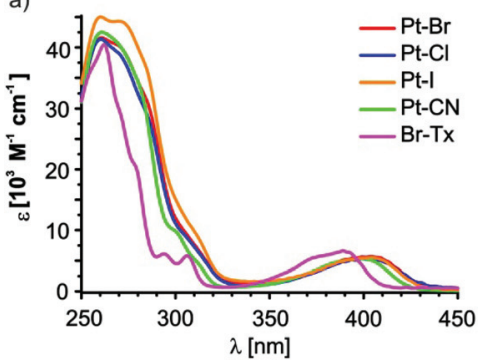

b)

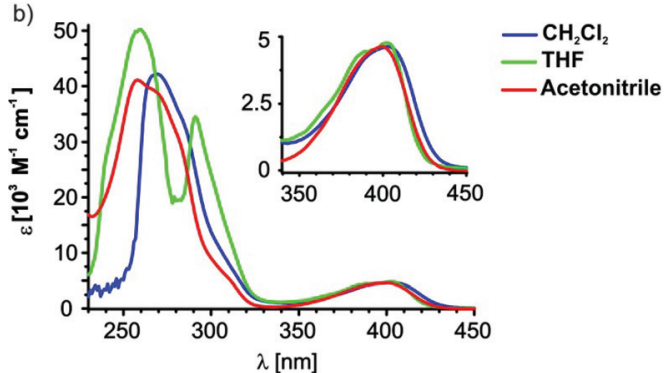

Fig. 5 (a) UV-Vis spectra in $\mathrm{CH}_{2} \mathrm{Cl}_{2}$ of $\mathrm{Pt}-\mathrm{Br}$, $\mathrm{Pt}-\mathrm{Cl}, \mathrm{Pt}-\mathrm{I}, \mathrm{Pt}-\mathrm{CN}$ and the ligand bromothioxanthone ( $\mathrm{Br}-\mathrm{Tx}$ ). (b) UV-Vis spectra of $\mathrm{Pt}-\mathrm{Br}$ in acetonitrile (red), $\mathrm{CH}_{2} \mathrm{Cl}_{2}$ (blue) and THF (green).

Table 2 Absorption data of the ligand $\mathrm{Br}-\mathrm{Tx}$ and the four complexes $\mathrm{Pt}-\mathrm{Cl}, \mathrm{Pt}-\mathrm{Br}, \mathrm{Pt}-\mathrm{CN}$ and $\mathrm{Pt}-\mathrm{I}$ (ca. $10^{-5} \mathrm{M}$ in $\mathrm{CH}_{2} \mathrm{Cl}_{2}, T=298 \mathrm{~K}$ ) and TD-DFT results of $\mathrm{Pt}-\mathrm{Br}$ and $\mathrm{Pt}-\mathrm{CN}$ in $\mathrm{CH}_{2} \mathrm{Cl}_{2}$; n.c. = not calculated

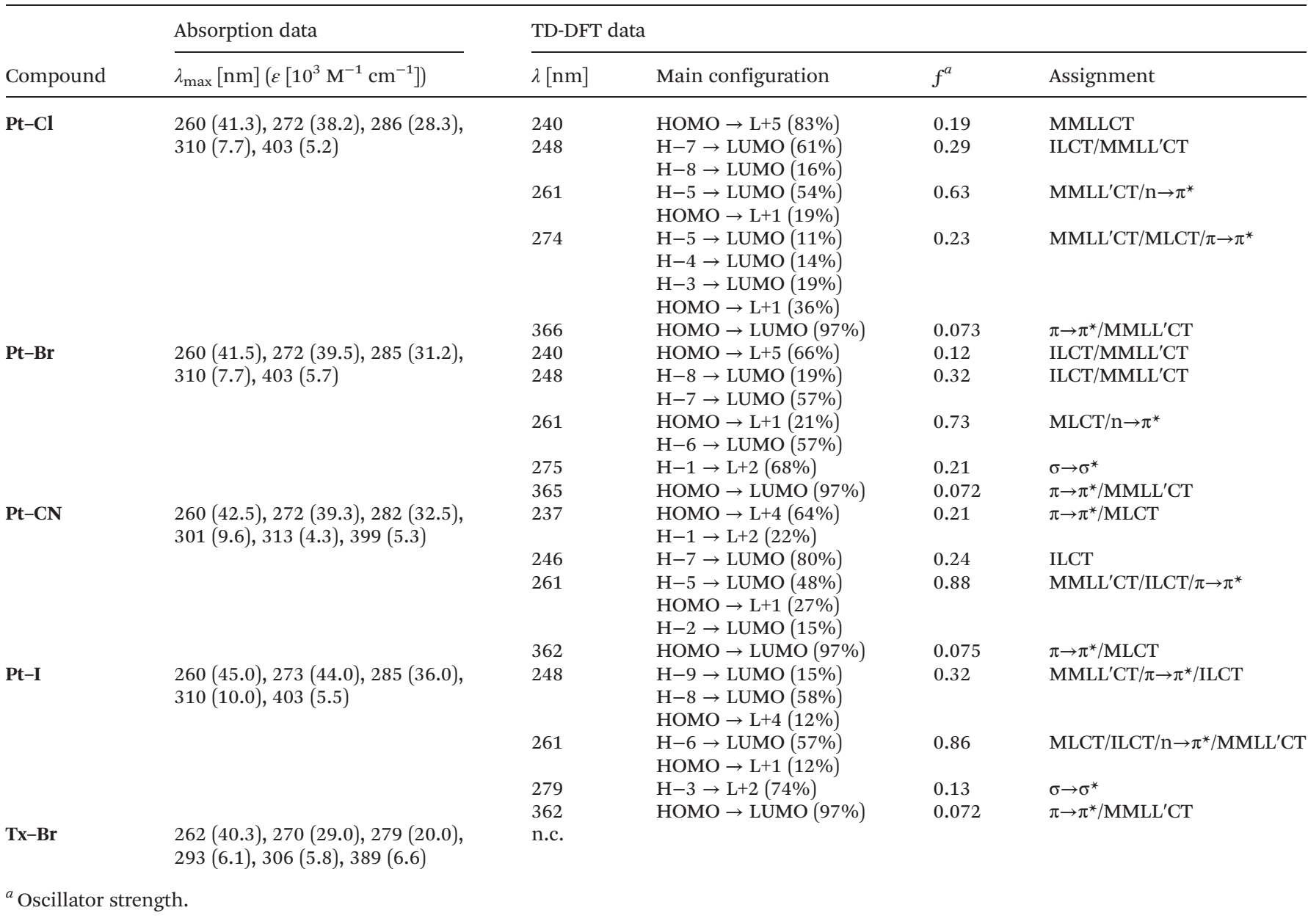

donor towards the thioxanthonyl core, thus lowering the HOMO-LUMO gap. ${ }^{100} \mathrm{~A}$ more precise explanation of the redshift is that the highest occupied platinum $\mathrm{d}$ orbital $5 \mathrm{~d}_{x z}$ is more strongly coupled to the $\pi$ than to the $\pi^{*}$ orbital of the thioxanthonyl ligand since the $\pi$ and the $5 \mathrm{~d}_{x z}$ orbitals are closer in energy. This leads to a destabilisation of the $\pi$ orbital while the $\pi^{*}$ orbital is stabilised by the interaction with the unoccupied Pt $6 \mathrm{p}_{z}$ orbital. Thus the energy gap of the $\pi \rightarrow \pi^{*}$ transition is lowered. ${ }^{78}$
As follows from our quantum chemical calculations (vide infra) the (relatively) weak low-energy band corresponds to the HOMO $\rightarrow$ LUMO transition while several individual transitions contribute to the stronger, structured UV absorption. The energy of the low-energy band remains nearly unchanged upon substitution of the $\mathrm{Br}^{-}$ligand by $\mathrm{I}^{-}$or $\mathrm{Cl}^{-}$ while it is shifted by $370 \mathrm{~cm}^{-1}$ to higher energy for the cyanido complex. This blue-shift is a result of the $\pi$-accepting ability of the cyanido ligand in trans-position to the Tx ligand, which 
stabilises the HOMO. This observation is also in accord with the ${ }^{13} \mathrm{C}$ NMR chemical shifts where the strong back bonding ability of the cyanido ligand induces a deshielding of the ipso carbon. Nevertheless, the effect of the ligand X on the HOMOLUMO gap is rather small. The electrochemical data of the four complexes derived from cyclic voltammetric experiments $\left(0.1 \mathrm{M} \mathrm{Bu}_{4} \mathrm{NPF}_{6} / \mathrm{CH}_{2} \mathrm{Cl}_{2} v=400 \mathrm{mV} \mathrm{s}^{-1}\right)$ also show a small effect of the X-ligand since the potentials of the first irreversible oxidation are all in a similar range of 0.94 to $1.09 \mathrm{~V}$ (see Fig. S18-S21 of the ESI; $\uparrow$ note, however, that the peak potentials of chemically irreversible processes do not strictly correspond to the thermodynamic $E^{0}$ values but are also affected by the equilibrium and forward rate constants of the chemical follow process).

Fig. 5b shows the electronic absorption spectra of $\mathbf{P t}-\mathbf{B r}$ at room temperature in different solvents. The position of the twin band at $400 \mathrm{~nm}$ reveals no solvent dependence whereas the onset of the UV band shifts to higher energy with increasing solvent polarity. Of note is also a distinct splitting of this latter band in THF whereas the lower energy components are only a shoulder superimposed on the more intense, higher energy one in the other solvents. From our observation that the split Vis band with individual peaks at $c a .400 \mathrm{~nm}$ and $390 \mathrm{~nm}$ exhibits no positional solvent dependence and closely resembles the Vis absorption of the free Tx ligand itself, we can infer that both relevant MOs are essentially confined to the $\sigma$-bonded Tx ligand and have obviously very similar spatial characteristics. In particular, the underlying transition(s) have no appreciable charge transfer character. Experimental and quantum chemical studies on thioxanthones point to mainly $\pi \rightarrow \pi^{*}$-character of the underlying transition(s). That assumption is further supported by our present TD-DFT calculations on Pt-Br, Pt-Cl, Pt-I and Pt-CN (Table 2, Fig. 6, and Fig. 25, 27 and 28 of the ESI $†$ ). These calculations indicate that the HOMO, the LUMO and the LUMO+1 are almost exclusively located on the thioxanthonyl moiety with major orbital coefficients on the intracyclic sulfur atom for the HOMO, at the thioxanthone carbonyl function for the LUMO and a nodal plane along the $\mathrm{S} \cdots \mathrm{CO}$ axis for the LUMO+1.

In contrast, the UV bands in the range of 310 to $260 \mathrm{~nm}$ possess negative solvatochromism which indicates charge

Table 3 Luminescence data of $\mathrm{Pt}-\mathrm{Br}, \mathrm{Pt}-\mathrm{Cl}, \mathrm{Pt}-\mathrm{I}$ and $\mathrm{Pt}-\mathrm{CN}$ in nitrogen-saturated and of $\mathrm{Br}-\mathrm{Tx}$ in aerated $\mathrm{CH}_{2} \mathrm{Cl}_{2}$ solutions at a concentration of $10^{-5} \mathrm{~mol} \mathrm{~L}^{-1} ;$ n.m. $=$ not measured

\begin{tabular}{llllll}
\hline & $\begin{array}{l}\lambda_{\max , \mathrm{Fl}}[\mathrm{nm}] \\
\left(\mathrm{St} \mathrm{Shift}^{-1}\right. \\
\left.\left[\mathrm{cm}^{-1}\right]\right)\end{array}$ & $\begin{array}{l}\lambda_{\max , \mathrm{Ph}}[\mathrm{nm}] \\
(\mathrm{St} \text { shift } \\
\left.\left[\mathrm{cm}^{-1}\right]\right)\end{array}$ & $\phi_{\mathrm{Fl}}$ & $\phi_{\mathrm{Ph}}$ & $\tau[\mu \mathrm{s}]$ \\
\hline Br-Tx & $417(1726)$ & - & n.m. & - & - \\
Pt-Cl & $451(2640)$ & $520(5583)$ & 0.006 & 0.188 & 2.17 \\
Pt-Br & $450 / 421^{a}(2592)$ & $517 / 491^{a}(5472)$ & 0.006 & $0.120 /$ & n.m. \\
& & & & $0.031^{a}$ & \\
Pt-I & $441(2138)$ & $511(5244)$ & 0.004 & 0.017 & n.m. \\
Pt-CN & $439(2283)$ & $507(5338)$ & 0.015 & 0.069 & n.m.
\end{tabular}

${ }^{a}$ Measured in benzene at ambient temperature in nitrogen saturated solutions. transfer contributions to at least one of the major transitions within the band envelope. According to our TD-DFT calculations, the overall UV absorption comprises four major components: an absorption at a (calculated) energy of $275 \mathrm{~nm}$, which is essentially the HOMO- $1 \rightarrow$ LUMO +2 transition, one very strong absorption at $261 \mathrm{~nm}$ mainly corresponding to the HOMO-6 $\rightarrow$ LUMO (57\%) and HOMO $\rightarrow$ LUMO+1 (21\%) transitions, a band at $248 \mathrm{~nm}$, which is dominated by the HOMO $-7 \rightarrow$ LUMO (57\%) and the HOMO-8 $\rightarrow$ LUMO (19\%) transitions, and one rather weak band at $240 \mathrm{~nm}$ of mainly HOMO $\rightarrow$ LUMO+5 origin. As follows from Fig. 6, the band calculated at $275 \mathrm{~nm}$ is a $\sigma \rightarrow \sigma^{*}$ transition of the $\mathrm{Br}-\mathrm{Pt}$ bond accompanied by an electron density increase at the $\mathrm{Br}^{-}$ligand and the occurrence of a nodal plane between the $\mathrm{Pt}$ and the $\mathrm{Br}$ atom. The band calculated at $261 \mathrm{~nm}$ is a mixture of an intraligand charge-transfer (ILCT) and $n \rightarrow \pi^{*}$ transition, both centred at the thioxanthonyl ligand with some shift of electron density from the $\mathrm{S}$ and $\mathrm{O}$ atoms to the carbon atoms of the thioxanthonyl moiety and a shift of electron density from the Pt bound aryl to the outermost phenyl ring. The $248 \mathrm{~nm}$ band comprises a thioxanthone-based intraligand charge transfer (ILCT) and a mixed metal/ligand-to-ligand' charge-transfer (MLL'CT) from the $\left\{\left(\mathrm{PEt}_{3}\right)_{2} \mathrm{Pt}\right\}$-unit to the thioxanthonyl ligand owing to appreciable Pt-aryl $\delta$ character of the HOMO-8. Of note is also an energy splitting of 0.28 to $0.29 \mathrm{eV}$ between the similar MOs HOMO-8 and HOMO-6, which represent the $\delta$-bonding and -antibonding interactions between the Pt atom and the Ptbonded aryl ring of the Tx ligand. The band at $240 \mathrm{~nm}$ has also some ILCT- and MLL'CT component. Similar results have been obtained for complexes Pt-CN, Pt-Cl and Pt-I (see Fig. S25, S27 and S28 of the ESI $\dagger$ ). However, the $\sigma \rightarrow \sigma^{*}$ transition of Pt-Br and Pt-I is absent in Pt-CN and $\mathbf{P t}-\mathbf{C l}$ as a result of the energetically low-lying MOs for the $\mathrm{Pt}-\mathrm{Cl}$ and $\mathrm{Pt}-\mathrm{CN} \sigma$-bonds.

\section{Luminescence spectroscopy}

Fig. 7a displays the room temperature emission spectra of $\mathbf{B r}-$ Tx in $10^{-5} \mathbf{M}$ aerated and of Pt-CN, Pt-I, Pt-Br and Pt-Cl in $10^{-5} \mathrm{M}$ nitrogen-saturated $\mathrm{CH}_{2} \mathrm{Cl}_{2}$ solutions. $\mathrm{Br}-\mathrm{Tx}$ emits at $417 \mathrm{~nm}$ upon irradiation at $370 \mathrm{~nm}$. Excitation at $400 \mathrm{~nm}$ into the HOMO $\rightarrow$ LUMO band of the four complexes results in dual emission at around $450 \mathrm{~nm}$ and at $c a .510 \mathrm{~nm}$. Stokes shifts are in the range of 2140 to $2640 \mathrm{~cm}^{-1}$ for the higher energy emission and of 5244 to $5583 \mathrm{~cm}^{1}$ for the one at the lower energy. We note here that the Stokes shifts of the higher energy emission band of the platinum complexes is only mildly larger as that of $1760 \mathrm{~cm}^{-1}$ for the fluorescence emission of $\mathbf{B r}-\mathbf{T x}$ itself and it is clearly different from that of $\mathbf{B r}-\mathbf{T x}$ in each case. For every complex, the emission band at $450 \mathrm{~nm}$ is insensitive against oxygen while that at $510 \mathrm{~nm}$ is almost completely quenched in aerated solutions (Fig. 7c). This observation in concert with the large Stokes shifts let us assign the high energy emission as fluorescence and the one at lower energy as phosphorescence, both arising from the $\sigma$-bonded Tx ligand. Excitation spectra of $\mathbf{P t}-\mathbf{C l}$ (see Fig. S32 of the ESI $\dagger$ ) support this assignment. Emission detection at wavelengths of 

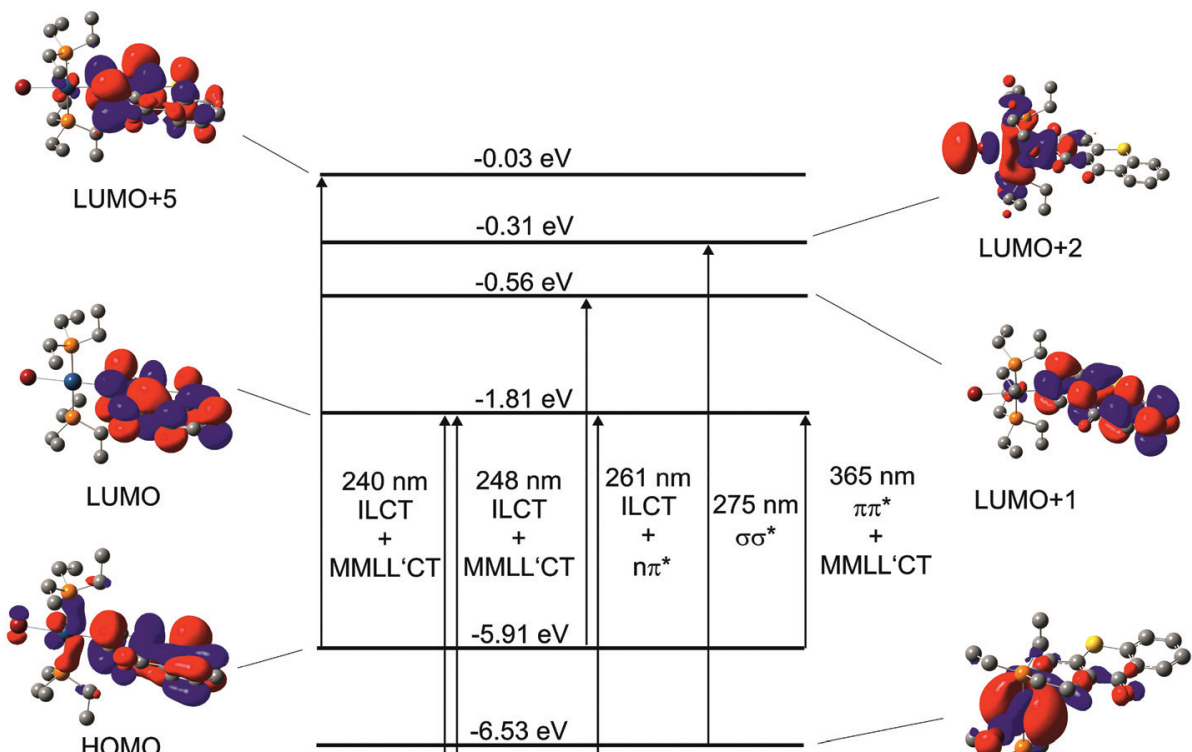

HOMO
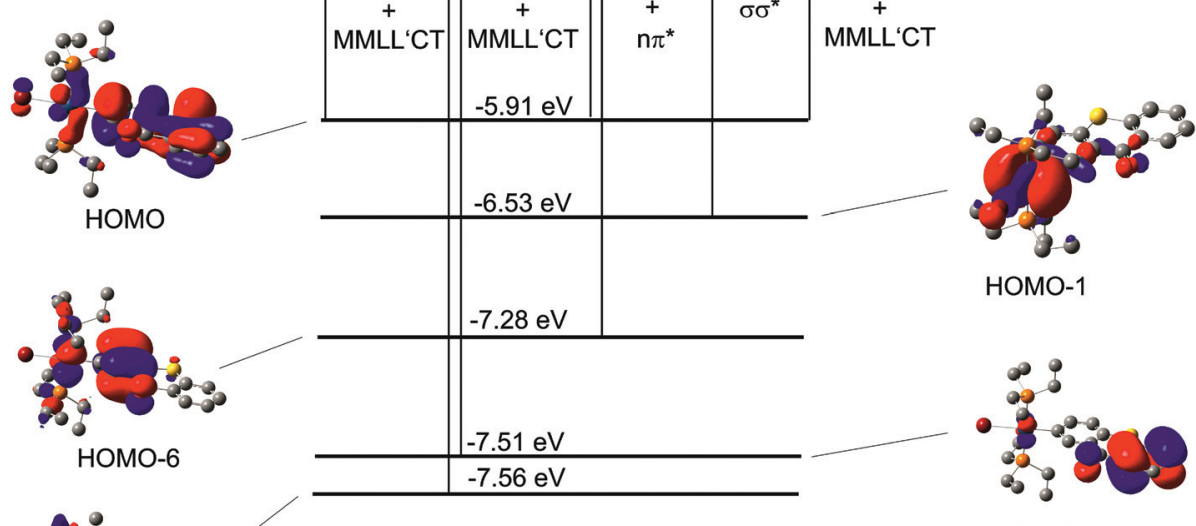

HOMO-7

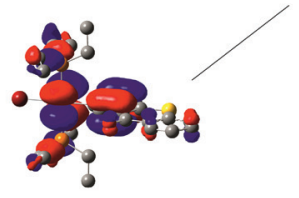

\section{HOMO-8}

Fig. 6 Graphical representations of selected MOs and their TD-DFT energies for complex Pt-Br. Arrows symbolise the main contributors to the respective transitions.
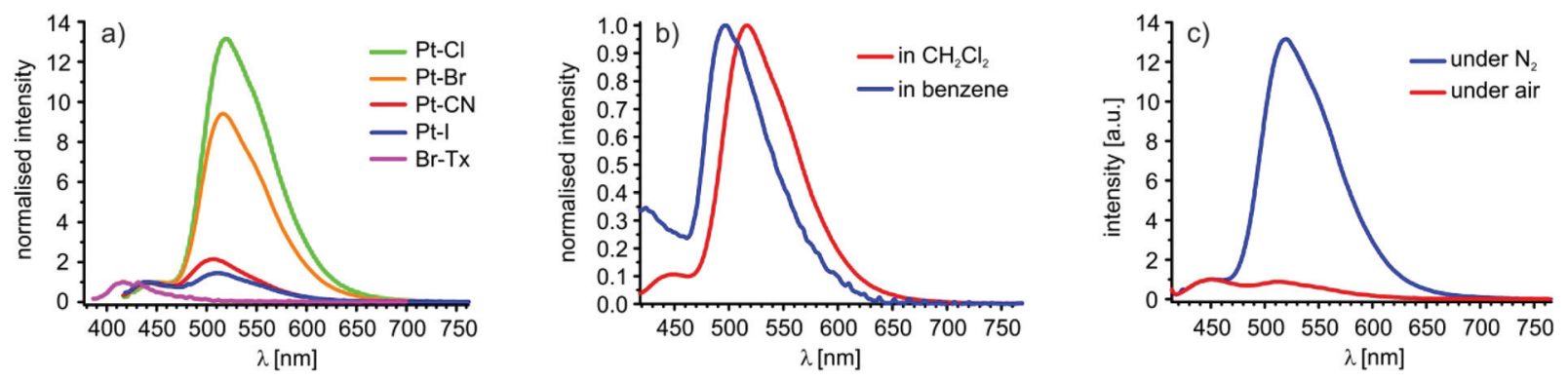

Fig. 7 (a) Emission spectra of $\mathrm{Pt}-\mathrm{Cl}$ (green), $\mathrm{Pt}-\mathrm{Br}$ (orange), $\mathrm{Pt}-\mathrm{CN}$ (red), and $\mathrm{Pt}-\mathrm{I}$ (blue) in nitrogen-saturated and $\mathrm{Br}-\mathrm{Tx}$ in aerated $\mathrm{CH}_{2} \mathrm{Cl}{ }_{2}$ solutions. (b) Emission spectra of $\mathrm{Pt}-\mathrm{Br}$ in $\mathrm{CH}_{2} \mathrm{Cl}_{2}$ (red), and benzene (blue). (c) Emission spectra of $\mathrm{Pt}-\mathrm{Cl}$ under nitrogen atmosphere (blue) and under air (red).

450 and $501 \mathrm{~nm}$ provide essentially identical spectra with a prominent band $400 \mathrm{~nm}$ in exact match with the low-energy $\pi \rightarrow \pi^{*}$ absorption of the Pt-bonded Tx substituent. In further agreement with that hypothesis dual emission from the complexes with attenuated intensities was also observed when Pt-Br was irradiated at 280, 350 or $400 \mathrm{~nm}$ (see Fig. S33 of the ESI $\dagger$ ). This clearly indicates that both emissions emanate from the same compound.
The influence of the ligand $\mathrm{X}$ on the emission energies is small, but both bands shift to slightly higher energy as $\mathrm{Pt}-\mathrm{X}$ back bonding increases $(\mathrm{Cl}<\mathrm{Br} \ll \mathrm{I}<\mathrm{CN})$. The wavelength of the fluorescence emission of the (pseudo)halogenido complexes thus follows an inverse order as that of the electronic absorption. One possible explanation is that the first excited singlet state undergoes some structural reorientation before emission occurs which leads to a stronger contribution 
of the (pseudo)halogenido ligand. Such structural reorientation upon irradiation of thioxanthones is not without precedence in the literature ${ }^{96}$ and also underlies the solvent dependency of Tx emission, very similar to the one that we observe for the investigated complexes (Fig. 7b). Computed structure changes between the $\mathrm{T}_{1}$ and $\mathrm{S}_{0}$ states are, however, rather minor and basically confined to the platinum bonded Tx ligand with a contraction of the $\mathrm{Pt}-\mathrm{C}(\mathrm{Tx})$ and the $\mathrm{C} 4-\mathrm{S}$ bond lengths of $c a .3 \mathrm{pm}$ and elongation of the $\mathrm{Tx} \mathrm{C}=\mathrm{O}$ and the $\mathrm{C} 1-\mathrm{C} 2$ bonds of about $4 \mathrm{pm}$ and $2 \mathrm{pm}$, respectively (Tables S5 to S8 of the ESI $\dagger$ ). The same holds for calculated spin densities as is exemplarily shown for Pt-Cl in Fig. S26 of the ESI. $\dagger$

For the three halogenido complexes the phosphorescence quantum yields increase with increasing $\sigma$-basicity of the ligand $\mathrm{X}$ against platinum in the order $\mathrm{I}<\mathrm{CN}<\mathrm{Br}<\mathrm{Cl}$ from smaller than $2 \%$ for Pt-I to close to $19 \%$ for Pt-Cl (Table 3 ). With increasing $\sigma$-basicity of the ligand $\mathrm{X}$, the ligand-field splitting also increases which in turn destabilises the nonemissive Pt $5 \mathrm{~d}$ states. Therefore, thermal excitation from the emissive thioxanthone-centred ${ }^{3} \pi \pi^{*}$-states to the Pt $5 \mathrm{~d}$ states undergoing radiationless decay is diminished. ${ }^{103}$ Ligand-field arguments would, however, predict that the cyanido complex is the strongest triplet emitter along this series of complexes, which is clearly not the case. Radiationless decay of the excited triplet state may also be triggered by excitation of vibrational quanta, and this decay channel may be particularly efficient in Pt-CN due to the high energy of the $\mathrm{C} \equiv \mathrm{N}$ stretch. ${ }^{104}$

The phosphorescence quantum yield further increases with increasing polarity of the solvent as is exemplified by complex Pt-Br, which shows a quantum yield of $12 \%$ in $\mathrm{CH}_{2} \mathrm{Cl}_{2}$ but only one of $3 \%$ in benzene. Such behaviour has also been reported for purely organic thioxanthones, which also show strong solvent dependence of the rates of internal conversion and intersystem crossing owing to a modulation of the relative energies of the $S_{1}, S_{2}, T_{1}$ and $T_{2}$ states. ${ }^{94-96}$ This effect is also reflected in the energies of the fluorescence and the phosphorescence bands of Pt-Br that are blue shifted by $1530 \mathrm{~cm}^{-1}$ and $1025 \mathrm{~cm}^{-1}$, respectively, when the solvent is changed from $\mathrm{CH}_{2} \mathrm{Cl}_{2}$ to benzene.

We note that the fluorescence quantum yields and, obviously, the lifetimes of the four complexes vary only very little and are also very similar to those of purely organic thioxanthones. ${ }^{88,94,96,105}$ The rate constant of fluorescence can be estimated as ca. 1.2 to $0.3 \mathrm{~ns}$ by the established equation: ${ }^{105}$

$$
\Phi_{\mathrm{f}}=k_{\mathrm{f}} \tau_{\mathrm{f}} \text { with } k_{\mathrm{f}}=5.12 \times 10^{7} \mathrm{~s}^{-1} \text {. }
$$

This shows that attachment of the $\left\{\mathrm{Pt}\left(\mathrm{PEt}_{3}\right) \mathrm{X}\right\}$-fragment has an only limited influence on the already high rate of intersystem crossing (ISC) of the Tx dye. The quantum yield of triplet formation of parent thioxanthone has been determined as $66 \%$ for acetonitrile and $84 \%$ for benzene solutions. ${ }^{97}$ Of note is, however, the observation of moderately to rather intense room-temperature phosphorescence from the thioxanthonyl ligand with quantum yields of up to almost 19\%. Organic thioxanthones, while being phosphorescent in glassy matrices at $77 \mathrm{~K},{ }^{89,90,94}$ usually show only very weak emission under these conditions, if any at all. ${ }^{97}$ Intersystem crossing from the excited $S_{1}$ to the excited $T_{2}$ state of thioxanthones is usually very fast (see Fig. 1) and occurs within $10 \mathrm{ps}^{86,95}$ while the Internal Conversion from the $T_{2}$ to the $T_{1}$ state occurs at a rate which is identical to the lifetime of the fluorescence (1.5-2 ns). ${ }^{86}$ In contrast, the $\mathrm{T}_{1}$ state is very long-lived with half-lives in the range of 100 to $140 \mathrm{~ms}$, making it very susceptible to quenching and photoreactions such as $\mathrm{H}$ atom abstraction. The role of the covalently bonded Pt centre is thus to open a pathway for relatively rapid decay of the $T_{1}$ state to the ground state with the emission of light due to its high spin-orbit coupling constant, which is not available for thioxanthone itself or its organic derivatives. Pt-Cl, the strongest triplet emitter of the present series, has a phosphorescence half-life of $2.17 \mu \mathrm{s}$, which is by five orders of magnitude lower compared to that of purely organic thioxanthones. The lifetime clearly proves that the emission band at $510 \mathrm{~nm}$ originates from a triplet state and further indicates that phosphorescence emission now becomes competitive to radiationless deactivation pathways.

\section{Conclusions}

Four new square-planar complexes trans-Pt $\left(\mathrm{PEt}_{3}\right)_{2}(\mathrm{X})$ (thioxanthon-2-yl) (X = Cl, Br, CN or I) were successfully synthesised by oxidative addition of 2-bromo-9H-thioxanthen-9-one to Pt$\left(\mathrm{PEt}_{3}\right)_{4}$ and subsequent halide exchange. Electronic absorption data in concert with TD-DFT calculations reveal a considerable red-shift of the thioxanthone-centred $\pi \rightarrow \pi^{*}$ (HOMO $\rightarrow$ LUMO) transition when compared to the free ligand in accordance with the overall donor capabilities of the trans- $\left\{\mathrm{Pt}\left(\mathrm{PEt}_{3}\right)_{2} \mathrm{X}\right\}$ fragment. All four complexes exhibit dual fluorescence and phosphorescence emission in fluid solution at room temperature arising from excited singlet and triplet states located at the thioxanthonyl ligand. While the fluorescence quantum yield is largely independent on $\mathrm{X}$ and very similar to that of other thioxanthones, that of the phosphorescence emission is strongly modulated by the ligand $\mathrm{X}$, ranging from $1.7 \%$ for Pt-I to a truly exceptional value of $18.8 \%$ for $\mathbf{P t - C l}$ in nitrogensaturated $\mathrm{CH}_{2} \mathrm{Cl}_{2}$ solution. In an intuitive ordering, the phosphorescence quantum yield of the halogenido complexes increases with the ligand-field splitting abilities of ligand $\mathrm{X}$. The lower phosphorescence quantum yield of the strongfield cyanido ligand may be due to its high-energy $\mathrm{C} \equiv \mathrm{N}$ stretch, which probably provides an efficient non-radiative deactivation channel. Key to the observation of dual emission is that the platinum coordination centre makes only limited contribution to the relevant frontier orbitals of the excited states $^{70-72}$ as is, e.g., seen by the computed spin density distributions of the $\mathrm{T}_{1}$ state. This attenuated $\mathrm{Pt}$ contribution has no noticeable influence on the already fast rate of ISC inherent to thioxanthones. It is, however, still sufficient to open a radiative deactivation channel for the usually very long-lived triplet state that is unattainable for thioxanthones themselves, thus diminishing the lifetime of the excited triplet state of the Tx ligand 
by five orders of magnitude to a value of $c a .2 \mu \mathrm{s}$. This allows for thioxanthone-based phosphorescence to be observed in fluid solution with unprecedentedly high quantum yield. We note here that complexes exhibiting dual fluorescence and phosphorescence emission have advantages over twocomponent sensors for quantitative detection of singletoxygen. ${ }^{71}$ The platinum Tx complexes herein display strong phosphorescence and quantitative quenching of that emission at atmospheric $\mathrm{O}_{2}$ levels while fluorescence emission is fully retained. This makes them promising candidates for such application, and work along these lines is underway.

\section{Experimental section}

\section{Materials and general methods}

All reactions, except the oxidative addition of 2-bromo- $9 \mathrm{H}$ thioxanthen-9-one (Br-Tx) to $\mathrm{Pt}\left(\mathrm{PEt}_{3}\right)_{4}$, were performed under air with undried solvents. THF was distilled from blue sodium/ benzophenone ketyl and was degassed by three freeze-pumpthaw cycles. All other solvents were used without further purification. 2-Bromo-9H-thioxanthen-9-one $(\mathbf{B r}-\mathbf{T x})^{106}$ and [Pt$\left.\left(\mathrm{PEt}_{3}\right)_{4}\right]^{107}$ were synthesised according to literature procedures.

NMR experiments were carried out on a Varian Unity Inova 400, a Bruker Avance III DRX 400 or a Bruker Avance DRX 600 spectrometer. ${ }^{1} \mathrm{H}$ and ${ }^{13} \mathrm{C}$ NMR spectra were referenced to the solvent signal. ${ }^{31} \mathrm{P}$ and ${ }^{195} \mathrm{Pt} \mathrm{NMR}$ spectra were referenced to external standard $\left(85 \% \mathrm{H}_{3} \mathrm{PO}_{4}\right.$ or saturated solution of $\mathrm{K}_{2}\left[\mathrm{PtCl}_{6}\right]$ in $\mathrm{D}_{2} \mathrm{O}$, respectively). NMR spectral data are given as follows: chemical shift ( $\delta \mathrm{ppm})$, multiplicity (m: multiplet, s: singlet, d: doublet, t: triplet, quin: quintet, vm: virtual multiplet,), coupling constant $(\mathrm{Hz})$, integration. In addition to $1 \mathrm{D}$ NMR experiments, complete NMR characterisations were performed by $2 \mathrm{D}$ NMR experiments $\left({ }^{1} \mathrm{H},{ }^{1} \mathrm{H}\right.$ gCOSY, ${ }^{1} \mathrm{H},{ }^{13} \mathrm{C}$ gHSQC, ${ }^{1} \mathrm{H},{ }^{13} \mathrm{C}$ gHMBC and ${ }^{1} \mathrm{H},{ }^{31} \mathrm{P}$ gHMBC).

$\mathrm{X}$-ray diffraction analysis was performed at $100 \mathrm{~K}$ on a STOE IPDS-II diffractometer equipped with a graphite-monochromated radiation source $(\lambda=0.71073 \AA)$ and an image plate detection system. A crystal mounted on a fine glass fiber with silicon grease was employed. If not indicated otherwise, the selection, integration and averaging procedure of the measured reflex intensities, the determination of the unit cell dimensions and a least-squares fit of the $2 \theta$ values as well as data reduction, LP-correction and space group determination were performed using the X-Area software package delivered with the diffractometer. A semiempirical absorption correction was performed. The structure of Pt-Cl was solved by the heavyatom methods (SHELXS-97), whereas that of Pt-CN was solved by direct methods (SHELXS-97). ${ }^{118}$ Solutions of both structures were completed with difference fourier syntheses and refined with full-matrix least-square using SHELXL-97 $7^{108}$ minimising $\omega\left(F_{0}{ }^{2}-F_{\mathrm{c}}{ }^{2}\right)^{2}$. Weighted $R$ factor ( $\left.\mathrm{w} R^{2}\right)$ and the goodness of fit GooF are based on $F^{2}$. All hydrogen atoms were treated according to a riding model. Molecular structures in this work are plotted with ORTEP 3. ${ }^{109}$ Hydrogen atoms and solvent molecules are omitted for clarity.
UV-Vis spectra were obtained on a TIDAS fiberoptic diode array spectrometer MCS UV/NIR from j\&m in HELLMA quartz cuvettes with $1 \mathrm{~cm}$ optical path lengths. Emission spectra were measured on a Perkin Elmer luminescence spectrometer LS50 using HELLMA quartz cuvettes modified with an angle valve from Normag. Time-resolved luminescence spectroscopy was measured on a LP920-KS instrument from Edinburgh Instruments, equipped with a R928 photomultiplier and an iCCD camera from Andor using a Starna quartz cuvette modified with an angle valve from Rotaflow. Luminescence was excited with the frequency-doubled output from a Quantel Brilliant b laser and the pulse length of approximately $10 \mathrm{~ns}$. The concentration of samples was $c a .1 .5 \times 10^{-5} \mathrm{M}$.

Electrochemical investigations in degassed dichloromethane were performed in a vacuum-tight one-compartment cell on a BAS CV50 potentiostat using Pt or glassy carbon disk electrodes from BAS as the working electrode, a platinum counter electrode and a silver pseudoreference electrode. Potentials were calibrated against the ferrocene/ferrocenium couple $\left(E^{0} \mathrm{Fc} / \mathrm{Fc}^{+}=0.000 \mathrm{~V}\right)$.

\section{Computational details}

The ground state electronic structures were calculated by density functional theory (DFT) methods using the Gaussian $09^{110}$ program packages. Quantum chemical studies were performed without any symmetry constraints. Open shell systems were calculated by the unrestricted Kohn-Sham approach (UKS). ${ }^{111}$ Geometry optimization followed by vibrational analysis was made either in vacuum or in solvent media. The quasirelativistic Wood-Boring small-core pseudopotentials $(\mathrm{MWB})^{112,113}$ and the corresponding optimized set of basis functions ${ }^{114}$ for Pt and 6-31G(d) polarized double- $\zeta$ basis set ${ }^{115}$ for the remaining atoms were employed together with the Perdew, Burke, Ernzerhof exchange and correlation functional (PBE0). ${ }^{116,117}$ Solvent effects were described by the polarizable conductor continuum model (PCM) $)^{118-121}$ with standard parameters for $\mathrm{CH}_{2} \mathrm{Cl}_{2}$. Absorption spectra and orbital energies were calculated using time-dependent DFT (TD-DFT) ${ }^{122}$ using the same functional/basis set combination mentioned above. For easier comparison with the experiment, the obtained absorption and emission energies were converted into wavelengths and broadened by a Gaussian distribution (full width at half maximum $=3000 \mathrm{~cm}^{-1}$ ) using the program GaussSum. ${ }^{123}$ Molecular orbitals were visualised with the GaussView program. $^{124}$

trans-Bromido(thioxanthon-2-yl)bis(triethylphosphine)platinum(II) (Pt-Br). In a $50 \mathrm{~mL}$ Schlenk tube $\mathrm{Pt}\left(\mathrm{PEt}_{3}\right)_{4}(1.26 \mathrm{~g}$, $1.89 \mathrm{mmol}$ ) and 2-bromo-9H-thioxanthen-9-one (549 $\mathrm{mg}$, $1.89 \mathrm{mmol}$ ) were suspended under nitrogen atmosphere in $10 \mathrm{~mL}$ of degassed THF. After stirring the yellow suspension for $1.5 \mathrm{~h}$ at room temperature complete consumption of $\mathrm{Pt}\left(\mathrm{PEt}_{3}\right)_{4}$ was observed by ${ }^{31} \mathrm{P}$ NMR experiments. The solvent was removed and the remaining yellow solid was washed with pentane $(3 \times 5 \mathrm{~mL})$. The product was extracted from the residue with toluene $(3 \times 5 \mathrm{~mL})$ and recrystallised from $7 \mathrm{~mL}$ of toluene. The needle shaped crystalline material was redis- 
solved in benzene and then frozen at $273 \mathrm{~K}$. The benzene was sublimed off in vacuo to yield $810 \mathrm{mg}$ of the yellow product. Yield: 59\%. ${ }^{1} \mathrm{H}$ NMR (600.2 MHz, $\left.\mathrm{CD}_{2} \mathrm{Cl}_{2}, 298 \mathrm{~K}\right) \delta 8.55\left(\mathrm{~d},{ }^{3} \mathrm{~J}_{\mathrm{HH}}\right.$ $=8.2 \mathrm{~Hz}, 1 \mathrm{H}, \mathrm{H} 9), 8.54\left(\mathrm{~s}\right.$, with satellites ${ }^{3} J_{\mathrm{PtH}}=71.3 \mathrm{~Hz}, 1 \mathrm{H}$, H13), $7.70\left(\mathrm{~d},{ }^{3} J_{\mathrm{HH}}=8.2 \mathrm{~Hz}\right.$, with satellites ${ }^{3} \mathrm{~J}_{\mathrm{PtH}}=63.4 \mathrm{~Hz}, 1 \mathrm{H}$, H2), 7.61-7.57 (m, 2H, H6, and H7), 7.44 (m, 1H, H8), 7.21 (d, $\left.{ }^{3} J_{\mathrm{HH}}=8.2 \mathrm{~Hz}, 1 \mathrm{H}, \mathrm{H} 3\right), 1.67(\mathrm{~m}, 12 \mathrm{H}, \mathrm{H} 14), 1.07(\mathrm{~m}, 18 \mathrm{H}$, H15). ${ }^{13} \mathrm{C}$ NMR (150.9 MHz, $\left.\mathrm{CD}_{2} \mathrm{Cl}_{2}, 298 \mathrm{~K}\right) \delta 179.6$ (s, C11), $142.7\left(\mathrm{t},{ }^{3} \mathrm{~J}_{\mathrm{PC}}=2.2 \mathrm{~Hz}\right.$, with satellites $\left.{ }^{2} J_{\mathrm{PtC}}=43.8 \mathrm{~Hz}, \mathrm{C} 2\right), 139.7$ $\left(\mathrm{t},{ }^{2} J_{\mathrm{PC}}=9.0 \mathrm{~Hz}\right.$, with satellites $\left.{ }^{1} J_{\mathrm{PtC}}=972 \mathrm{~Hz}, \mathrm{C} 1\right), 138.3(\mathrm{~s}$, C5), $137.5\left(\mathrm{t},{ }^{3} J_{\mathrm{PC}}=2.7 \mathrm{~Hz}\right.$, with satellites $\left.{ }^{2} J_{\mathrm{PtC}}=50.4 \mathrm{~Hz}, \mathrm{C} 13\right)$, 132.2 (s, C7), 130.7 (t, $\left.{ }^{5} J_{\mathrm{PC}}=1.4 \mathrm{~Hz}, \mathrm{C} 4\right), 130.3$ (s, C10), 130.0 (s, C9), $129.1\left(\mathrm{t},{ }^{4} J_{\mathrm{PC}}=1.2 \mathrm{~Hz}, \mathrm{C} 12\right), 126.6$ (s, C6), $126.2(\mathrm{~s}, \mathrm{C} 8)$, 125.2 (s, with satellites ${ }^{3} J_{\mathrm{PtC}}=72.8 \mathrm{~Hz}, \mathrm{C} 3$ ), 14.8 (vquin, $J=$ $16.9 \mathrm{~Hz}, \mathrm{C} 14)$, and 8.1 (s, with satellites $\left.{ }^{3} \mathrm{~J}_{\mathrm{PtC}}=24.5 \mathrm{~Hz}, \mathrm{C} 15\right)$. ${ }^{31} \mathrm{P}$ NMR (162 MHz, $\left.\mathrm{CD}_{2} \mathrm{Cl}_{2}, 298 \mathrm{~K}\right) \delta 11.91$ (s, with satellites $\left.{ }^{1} J_{\mathrm{PtP}}=2701 \mathrm{~Hz}\right) .{ }^{195} \mathrm{Pt} \mathrm{NMR}\left(85.6 \mathrm{MHz}, \mathrm{CD}_{2} \mathrm{Cl}_{2}, 298 \mathrm{~K}\right) \delta-4382$ $\left(\mathrm{t},{ }^{1} J_{\mathrm{PtP}}=2701 \mathrm{~Hz}\right)$. Anal. Calcd for $\mathrm{C}_{25} \mathrm{H}_{37} \mathrm{BrOP}_{2} \mathrm{PtS}$ : C, 41.56; 5.16. Found: C, 42.11; H, 5.30\%.

trans-Chlorido(thioxanthon-2-yl)bis(triethylphosphine)platinum(II) (Pt-Cl). Pt-Br (46.5 mg, $64.4 \mu \mathrm{mol})$ and $\mathrm{AgBF}_{4}$ $(12.6 \mathrm{mg}, 64.4 \mu \mathrm{mol})$ were suspended in $3 \mathrm{~mL}$ of methanol and heated at $65{ }^{\circ} \mathrm{C}$ for $10 \mathrm{~min}$. $\mathrm{NaCl}(8 \mathrm{mg}, 137 \mu \mathrm{mol})$ was added and the yellow suspension was stirred for $16 \mathrm{~h}$ at room temperature. The precipitate was filtered off and solvent was removed from the filtrate. The remaining yellow solid was washed with water $(3 \times 5 \mathrm{~mL})$ and recrystallised from toluene to give $27.5 \mathrm{mg}$ of yellow, needle shaped crystals. (Yield: 63\%). ${ }^{1} \mathrm{H}$ NMR (600.33 MHz, $\mathrm{CD}_{2} \mathrm{Cl}_{2}, 298 \mathrm{~K}$ ) $\delta 8.55$ (s, with satellites $\left.{ }^{3} J_{\mathrm{PtH}}=69.2 \mathrm{~Hz}, 1 \mathrm{H}, \mathrm{H} 13\right), 8.54(\mathrm{~m}, 1 \mathrm{H}, \mathrm{H} 9), 7.71\left(\mathrm{dd},{ }^{3} J_{\mathrm{HH}}=\right.$ $8.13 \mathrm{~Hz},{ }^{4} J_{\mathrm{HH}}=1.24 \mathrm{~Hz}$, with satellites $\left.{ }^{3} J_{\mathrm{PtH}}=61.9 \mathrm{~Hz}, 1 \mathrm{H}, \mathrm{H} 2\right)$, $7.59(\mathrm{~m}, 2 \mathrm{H}, \mathrm{H} 6$, and $\mathrm{H} 7), 7.44(\mathrm{~m}, 1 \mathrm{H}, \mathrm{H} 8), 7.19\left(\mathrm{~d},{ }^{3} J_{\mathrm{HH}}=\right.$ $8.13 \mathrm{~Hz}, 1 \mathrm{H}, \mathrm{H} 3), 1.62$ (m, 12H, H14), 1.08 (m, 18H, H15). ${ }^{13} \mathrm{C}$ NMR (151.0 MHz, $\left.\mathrm{CD}_{2} \mathrm{Cl}_{2}, 298 \mathrm{~K}\right) \delta 180.2(\mathrm{~s}, \mathrm{C} 11), 143.0\left(\mathrm{t},{ }^{3} J_{\mathrm{PC}}\right.$ $=2.0 \mathrm{~Hz}$, with satellites $\left.{ }^{2} J_{\mathrm{PtC}}=43.0 \mathrm{~Hz}, \mathrm{C} 2\right), 138.3$ (s, C5), 137.8 $\left(\mathrm{t},{ }^{2} J_{\mathrm{PC}}=9.2 \mathrm{~Hz}\right.$, with satellites $\left.{ }^{1} J_{\mathrm{PtC}}=960 \mathrm{~Hz}, \mathrm{C} 1\right), 137.7\left(\mathrm{t},{ }^{3} J_{\mathrm{PC}}\right.$ $=2.56 \mathrm{~Hz}$, with satellites $\left.{ }^{2} \mathrm{~J}_{\mathrm{PtC}}=48.2 \mathrm{~Hz}, \mathrm{C} 13\right), 132.19(\mathrm{~s}, \mathrm{C} 7)$, $130.5\left(\mathrm{t},{ }^{5} J_{\mathrm{PC}}=1.38 \mathrm{~Hz}, \mathrm{C} 4\right), 130.3$ (s, C10), 130.0 (s, C9), 129.0 (s, with satellites $\left.{ }^{3} J_{\mathrm{PtC}}=70.5 \mathrm{~Hz}, \mathrm{C} 12\right), 126.6(\mathrm{~s}, \mathrm{C} 6), 126.2(\mathrm{~s}$, C8), 125.1 (s, with satellites ${ }^{3} J_{\mathrm{PtC}}=71.1 \mathrm{~Hz}, \mathrm{C} 3$ ), 14.2 (vquin, $J=$ $16.9 \mathrm{~Hz}, \mathrm{C} 14), 8.1$ (s, with satellites $\left.{ }^{2} J_{\mathrm{PtC}}=23.5 \mathrm{~Hz}, \mathrm{C} 15\right) .{ }^{31} \mathrm{P}$ NMR (161.84 MHz, $\left.\mathrm{CD}_{2} \mathrm{Cl}_{2}, 298 \mathrm{~K}\right) \delta 13.93$ (s, with satellites $\left.{ }^{1} J_{\mathrm{PtP}}=2725 \mathrm{~Hz}, 2 \mathrm{P}\right) .{ }^{195} \mathrm{Pt} \mathrm{NMR}\left(85.6 \mathrm{MHz}, \mathrm{CD}_{2} \mathrm{Cl}_{2}, 298 \mathrm{~K}\right)$ $\delta-4257\left(\mathrm{t},{ }^{1} J_{\mathrm{PtP}}=2725 \mathrm{~Hz}\right)$. Anal. Calcd for $\mathrm{C}_{25} \mathrm{H}_{37} \mathrm{ClOP}_{2} \mathrm{PtS}: \mathrm{C}$, 44.28; 5.50. Found: C, 44.28; H, 5.37\%. Crystals suitable for $\mathrm{X}$-ray diffraction analysis were obtained by slow evaporation of the solvent from a saturated $\mathrm{CH}_{2} \mathrm{Cl}_{2}$ solution.

trans-Cyanido(thioxanthon-2-yl)bis(triethylphosphine)platinum(II) (Pt-CN). Pt-Br (41 mg, 56.7 mmol) and AgCN (7.6 mg, $56.7 \mu \mathrm{mol}$, prepared from $\mathrm{AgNO}_{3}$ and $\mathrm{KCN}$ ) were suspended in $0.5 \mathrm{~mL}$ of acetone and heated at reflux for $5 \mathrm{~min}$. The obtained solid was filtered off through a syringe filter and the filter cake was washed with $\mathrm{CH}_{2} \mathrm{Cl}_{2}(2 \times 2 \mathrm{~mL})$. The solvent was removed from the combined filtrates and the pure yellow product was obtained by recrystallisation from acetone. (Yield: $89 \%$ ). ${ }^{1} \mathrm{H}$ NMR (600.33 MHz, $\left.\mathrm{CD}_{2} \mathrm{Cl}_{2}, 298 \mathrm{~K}\right) \delta 8.55\left(\mathrm{~d},{ }^{3} J_{\mathrm{HH}}=8.0 \mathrm{~Hz}, 1 \mathrm{H}\right.$,
H9), 8.50 (s, with satellites $\left.{ }^{3} J_{\mathrm{PtH}}=45.1 \mathrm{~Hz}, 1 \mathrm{H}, \mathrm{H} 13\right), 7.61$ (d, ${ }^{3} J_{\mathrm{HH}}=8.0 \mathrm{~Hz}$, with satellites $\left.{ }^{3} J_{\mathrm{PtH}}=40.9 \mathrm{~Hz}, 1 \mathrm{H}, \mathrm{H} 2\right), 7.60-7.57$ (m, 2H, H6 and H7), $7.44(\mathrm{~m}, 1 \mathrm{H}, \mathrm{H} 8), 7.29\left(\mathrm{~d},{ }^{3} J_{\mathrm{HH}}=8.0 \mathrm{~Hz}\right.$, $1 \mathrm{H}, \mathrm{H} 3), 1.73(\mathrm{~m}, 12 \mathrm{H}, \mathrm{H} 14)$, and $1.10\left(\mathrm{dt},{ }^{3} \mathrm{~J}_{\mathrm{HH}}=7.6 \mathrm{~Hz},{ }^{3} J_{\mathrm{PH}}=\right.$ $16.8 \mathrm{~Hz}, 18 \mathrm{H}, \mathrm{H} 15) .{ }^{13} \mathrm{C}$ NMR (151.0 MHz, $\left.\mathrm{CD}_{2} \mathrm{Cl}_{2}, 298 \mathrm{~K}\right) \delta$ 180.5 (s, C11), $151.3\left(\mathrm{t},{ }^{2} J_{\mathrm{PC}}=10.5 \mathrm{~Hz}, \mathrm{C} 1\right), 143.5\left(\mathrm{t},{ }^{3} J_{\mathrm{PC}}=2.2 \mathrm{~Hz}\right.$, with satellites $\left.{ }^{3} J_{\mathrm{PtC}}=27.9 \mathrm{~Hz}, \mathrm{C} 2\right), 138.5\left(\mathrm{t},{ }^{3} J_{\mathrm{PC}}=2.6 \mathrm{~Hz}\right.$, with satellites $\left.{ }^{2} J_{\mathrm{PtC}}=31.1 \mathrm{~Hz}, \mathrm{C} 13\right), 138.3(\mathrm{~s}, \mathrm{C} 5), 133.7\left(\mathrm{t},{ }^{2} J_{\mathrm{PC}}=\right.$ 12.4 Hz, C(CN)), 132.2 (s, C7), 131.3 (s, C4), 130.5 (s, C10), 130.0 (s, C9), 129.0 (s, C12), 126.6 (s, C6), 126.2 (s, C8), 125.2 (s, with satellites ${ }^{3} J_{\mathrm{PtC}}=49.9 \mathrm{~Hz}, \mathrm{C} 3$ ), 16.1 (vquin, $J=17.60 \mathrm{~Hz}, \mathrm{C} 14$ ), and 8.3 (s, with satellites $\left.{ }^{3} J_{\mathrm{PtC}}=24.4 \mathrm{~Hz}, \mathrm{C} 15\right) .{ }^{31} \mathrm{P}$ NMR $(161.84 \mathrm{MHz}$, $\left.\mathrm{CD}_{2} \mathrm{Cl}_{2}, 298 \mathrm{~K}\right) \delta 10.73$ (s, with satellites ${ }^{1} J_{\mathrm{PtP}}=2524 \mathrm{~Hz}, 2 \mathrm{P}$ ). ${ }^{195} \mathrm{Pt}$ NMR (85.6 MHz, $\left.\mathrm{CD}_{2} \mathrm{Cl}_{2}, 298 \mathrm{~K}\right) \delta-4674\left(\mathrm{t},{ }^{1} J_{\mathrm{PtP}}=2524\right.$ $\mathrm{Hz}$ ). Anal. Calcd for $\mathrm{C}_{26} \mathrm{H}_{37} \mathrm{NOP}_{2} \mathrm{PtS}$ : C, 46.70; H, 5.58; N, 2.09; S, 4.80. Found: C, 46.52; H, 5.60, N, 2.19; S, 4.69\%. Crystals suitable for X-ray diffraction analysis were obtained by slow evaporation of the solvent from a saturated $\mathrm{CH}_{2} \mathrm{Cl}_{2}$ solution.

\section{trans-Iodido(thioxanthonyl)bis(triethylphosphine)platinum}

(II) (Pt-I). Pt-Br (20 mg, $27.7 \mu \mathrm{mol})$ and AgOTf $(10.7 \mathrm{mg}$, $41.5 \mu \mathrm{mol}$ ) were combined in methanol and heated to reflux for $5 \mathrm{~min}$. $\mathrm{NaI}(8.3 \mathrm{mg}, 55.4 \mu \mathrm{mol})$ was added and the reaction mixture was stirred at ambient temperature for $1 \mathrm{~h}$. The beigeyellowish precipitate was filtered off and the solvent was removed from the filtrate. The remaining yellow solid was redissolved in benzene and filtered through a syringe filter. The solvent was removed and the yellow product washed with pentane $(3 \times 1.5 \mathrm{~mL})$ and dried in vacuo. (Yield: $89 \%) .{ }^{1} \mathrm{H}$ NMR $\left(600.2 \mathrm{MHz}, \mathrm{CD}_{2} \mathrm{Cl}_{2}, 298 \mathrm{~K}\right) \delta 8.55\left(\mathrm{~d},{ }^{3} J_{\mathrm{HH}}=8.0 \mathrm{~Hz}, 1 \mathrm{H}, \mathrm{H} 9\right)$, 8.52 (s, with satellites $\left.{ }^{3} J_{\mathrm{PtH}}=71.9 \mathrm{~Hz}, 1 \mathrm{H}, \mathrm{H} 13\right), 7.66\left(\mathrm{dd},{ }^{3} J_{\mathrm{HH}}\right.$ $=8.1 \mathrm{~Hz},{ }^{4} J_{\mathrm{HH}}=1.5 \mathrm{~Hz}$, with satellites $\left.{ }^{3} J_{\mathrm{PtH}}=64.0 \mathrm{~Hz}, 1 \mathrm{H}, \mathrm{H} 2\right)$, 7.62-7.58 (m, 2H, H6, and H7), 7.45 (m, 1H, H8), 7.23 (d, broad, $\left.{ }^{3} J_{\mathrm{HH}}=8.1 \mathrm{~Hz}, 1 \mathrm{H}, \mathrm{H} 3\right), 1.77(\mathrm{~m}, 12 \mathrm{H}, \mathrm{H} 14)$, and 1.05 $\left(\mathrm{dt},{ }^{3} J_{\mathrm{HH}}=7.7 \mathrm{~Hz},{ }^{3} J_{\mathrm{PH}}=16.4 \mathrm{~Hz}, 18 \mathrm{H}, \mathrm{H} 15\right) .{ }^{13} \mathrm{C} \mathrm{NMR}$ (150.9 MHz, $\left.\mathrm{CD}_{2} \mathrm{Cl}_{2}, 298 \mathrm{~K}\right) \delta 180.3(\mathrm{~s}, \mathrm{C} 11), 143.7\left(\mathrm{t},{ }^{2} J_{\mathrm{PC}}=8.8\right.$ $\mathrm{Hz}, \mathrm{C} 1$ ), 142.3 (s, with satellites $\left.{ }^{2} J_{\mathrm{PtC}}=44.4 \mathrm{~Hz}, \mathrm{C} 2\right), 138.3$ (s, C5), 137.2 (s, with satellites $\left.{ }^{2} J_{\mathrm{PtC}}=49.9 \mathrm{~Hz}, \mathrm{C} 13\right), 132.3$ (s, C8), 130.9 (s, C4), 130.3 (s, C10), 130.0 (s, C9), 129.1 (s,C12), 126.6 (s, C6), 126.3 (s, C8), 125.3 (s, with satellites ${ }^{3} J_{\mathrm{PtC}}=74.5 \mathrm{~Hz}, \mathrm{C} 3$ ), 16.0 (vquin, $J=17.4 \mathrm{~Hz}, \mathrm{C} 14$ ), and 8.2 (s, with satellites ${ }^{3} J_{\mathrm{PtC}}=$ 25.0 Hz, C15). ${ }^{31} \mathrm{P}$ NMR (161.84 MHz, $\left.\mathrm{CD}_{2} \mathrm{Cl}_{2}, 298 \mathrm{~K}\right) \delta 8.39(\mathrm{~s}$, with satellites $\left.{ }^{1} J_{\mathrm{PtP}}=2668 \mathrm{~Hz}, 2 \mathrm{P}\right) .{ }^{195} \mathrm{Pt} \mathrm{NMR}(85.6 \mathrm{MHz}$, $\left.\mathrm{CD}_{2} \mathrm{Cl}_{2}, 298 \mathrm{~K}\right) \delta-4602\left(\mathrm{t},{ }^{1} J_{\mathrm{PtP}}=2668 \mathrm{~Hz}\right)$. Anal. Calcd for $\mathrm{C}_{25} \mathrm{H}_{37} \mathrm{IOP}_{2} \mathrm{PtS}$ : C, 39.02; 4.85. Found: C, 38.46; H, 4.40\%.

\section{Acknowledgements}

We gratefully acknowledge the Deutsche Forschungsgemeinschaft (DFG) for financial support (grant number Wi1262 10/1). We further thank Dr Inigo Göttker gen. Schnetman and Bernhard Weibert for measurements and solutions of the single crystal X-ray diffraction data, Jun.-Prof. Dominik Wöll for providing a sample of 2-bromo-9H-thioxanthen-9-one to us and Prof. Dr Ulrich Steiner, Konstanz and Dr Stanislav Záliš, Prague, for helpful discussions. We also thank 
Prof. Oliver Wenger, University of Basel, for making his equipment for measuring the phosphorescence lifetime of complex Pt-Cl available to us and Julia Nomrovski for her help with the measurements. We are indebted to the state of Baden-Württemberg and the Deutsche Forschungsgemeinschaft for providing the computational facilities of the bwUni cluster to us.

\section{References}

1 M. A. Baldo, D. F. O’Brien, Y. You, A. Shoustikov, S. Sibley, M. E. Thompson and S. R. Forrest, Nature, 1998, 395, 151154.

2 R. D. Costa, E. Ortí, H. J. Bolink, F. Monti, G. Accorsi and N. Armaroli, Angew. Chem., Int. Ed., 2012, 51, 8178-8211.

3 R. Visbal and M. C. Gimeno, Chem. Soc. Rev., 2014, 43, 3551-3574.

4 L. F. Gildea and J. A. G. Williams, in Organic Light-Emitting Diodes (OLEDs), ed. A. Buckley, Woodhead Publishing, 2013, pp. 77-113, DOI: 10.1533/9780857098948.1.77.

5 D.-L. Ma, V. P.-Y. Ma, D. S.-H. Chan, K.-H. Leung, H.-Z. He and C.-H. Leung, Coord. Chem. Rev., 2012, 256, 30873113.

6 K. Li, G. Cheng, C. Ma, X. Guan, W.-M. Kwok, Y. Chen, W. Lu and C.-M. Che, Chem. Sci., 2013, 4, 2630-2644.

7 D.-L. Ma, H.-Z. He, K.-H. Leung, D. S.-H. Chan and C.-H. Leung, Angew. Chem., Int. Ed., 2013, 52, 7666-7682.

8 K. K.-W. Lo and S. P.-Y. Li, in Molecular Design and Applications of Photofunctional Polymers and Materials, 2012, vol. 2, pp. 130-198.

9 Q. Zhao, C. Huang and F. Li, Chem. Soc. Rev., 2011, 40, 2508-2524.

10 P. K. M. Siu, S.-W. Lai, W. Lu, N. Zhu and C.-M. Che, Eur. J. Inorg. Chem., 2003, 2749-2752.

11 V. Guerchais and J.-L. Fillaut, Coord. Chem. Rev., 2011, 255, 2448-2457.

12 Q. Zhao, F. Li and C. Huang, Chem. Soc. Rev., 2010, 39, 3007-3030.

13 K. K.-W. Lo, A. W.-T. Choi and W. H.-T. Law, Dalton Trans., 2012, 41, 6021-6047.

14 Z. Liu, W. He and Z. Guo, Chem. Soc. Rev., 2013, 42, 15681600.

15 H.-B. Xu, L.-X. Shi, E. Ma, L.-Y. Zhang, Q.-H. Wei and Z.-C. Chen, Chem. Commun., 2006, 1601-1603.

16 T. K. Ronson, T. Lazarides, H. Adams, S. J. A. Pope, D. Sykes, S. Faulkner, S. J. Coles, M. B. Hursthouse, W. Clegg, R. W. Harrington and M. D. Ward, Chem. - Eur. J., 2006, 12, 9299-9313.

17 W. T. Eckenhoff and R. Eisenberg, Dalton Trans., 2012, 41, 13004-13021.

18 J. A. G. Williams, Top. Curr. Chem., 2007, 281, 205-268.

19 L. J. Rothberg and A. J. Lovinger, J. Mater. Res., 1996, 11, 3174-3187.

20 H. Yersin, Top. Curr. Chem., 2004, 241, 1-26.

21 P.-T. Chou, Y. Chi, M.-W. Chung and C.-C. Lin, Coord. Chem. Rev., 2011, 255, 2653-2665.
22 J. Schneider, P. Du, P. Jarosz, T. Lazarides, X. Wang, W. W. Brennessel and R. Eisenberg, Inorg. Chem., 2009, 48, 4306-4316.

23 J. A. G. Williams, A. Beeby, E. S. Davies, J. A. Weinstein and C. Wilson, Inorg. Chem., 2003, 42, 8609-8611.

24 W. J. Brooks, V. Babayan, S. Lemansky, P. I. Djurovich, I. Tsyba, R. Bau and M. E. Thompson, Inorg. Chem., 2002, 41, 3055-3066.

25 S. J. Farley, D. L. Rochester, A. L. Thompson, J. A. K. Howard and J. A. G. Williams, Inorg. Chem., 2005, 44, 9690-9703.

26 S.-W. Lai, M. C.-W. Chan, T.-C. Cheung, S.-M. Peng and C.-M. Che, Inorg. Chem., 1999, 38, 4046-4055.

27 J. H. K. Yip, Suwarno and J. J. Vittal, Inorg. Chem., 2000, 39, 3537-3543.

28 S.-W. Lai and C.-M. Che, Top. Curr. Chem., 2004, 241, 27-63.

29 A. S. Ionkin, W. J. Marshall and Y. Wang, Organometallics, 2005, 24, 619-627.

30 S. C. F. Kui, I. H. T. Sham, C. C. C. Cheung, C.-W. Ma, B. Yan, N. Zhu, C.-M. Che and W.-F. Fu, Chem. - Eur. J., 2007, 7, 417-435.

31 J. Schneider, P. Du, X. Wang, W. W. Brennessel and R. Eisenberg, Inorg. Chem., 2009, 48, 1498-1506.

32 Y. Chi and P.-T. Chou, Chem. Soc. Rev., 2010, 39, 638-655.

33 Z. Wang, E. Turner, V. Mahoney, S. Madakuni, T. Groy and J. Li, Inorg. Chem., 2010, 49, 11276-11286.

34 W. Wu, H. Guo, S. Ji and J. Zhao, Inorg. Chem., 2011, 50, 11446-11460.

35 D. P. Rillema, A. J. Cruz, C. Moore, K. Siam, A. Jehan, D. Base, T. Nguyen and W. Huang, Inorg. Chem., 2012, 52, 596-607.

36 A. Tronnier, A. Risler, N. Langer, G. Wagenblast, I. Münster and T. Strassner, Organometallics, 2012, 31, 7447-7452.

37 H. Uesugi, T. Tsukuda, K. Takao and T. Tsubomura, Dalton Trans., 2013, 42, 7396-7403.

38 J. Moussa, T. Cheminel, G. R. Freeman, L.-M. Chamoreau, J. A. G. Williams and H. Amouri, Dalton Trans., 2014, 43, 8162-8165.

39 W. Wu, W. Wu, S. Ji, H. Guo, P. Song, K. Han, L. Chi, J. Shao and J. Zhao, J. Mater. Chem., 2010, 20, 97759786.

40 Y. Zhang, J. A. Garg, C. Michelin, T. Fox, O. Blacque and K. Venkatesan, Inorg. Chem., 2011, 50, 1220-1228.

41 Y. Zhang, J. Clavadetscher, M. Bachmann, O. Blacque and K. Venkatesan, Inorg. Chem., 2014, 53, 756-771.

42 Y. Unger, D. Meyer, O. Molt, C. Schildknecht, I. Münster, G. Wagenblast and T. Strassner, Angew. Chem., Int. Ed., 2010, 49, 10214-10216.

43 Y. Unger, A. Zeller, M. A. Taige and T. Strassner, Dalton Trans., 2009, 4786-4794, DOI: 10.1039/b900655a.

44 W. Lu, M. C. W. Chan, Z. Hui, C.-M. Che, N. Zhu and S.-T. Lee, J. Am. Chem. Soc., 2004, 126, 4958-4971.

45 W. Lu, M. C. W. Chan, N. Zhu, C.-M. Che, C. Li and Z. Hui, J. Am. Chem. Soc., 2004, 126, 7639-7651. 
46 C. E. Whittle, J. A. Weinstein, M. W. George and K. S. Schanze, Inorg. Chem., 2001, 40, 4053-4062.

47 M. Hissler, W. B. Connick, D. K. Geiger, J. E. McGarrah, D. Lipa, R. J. Lachiotte and R. Eisenberg, Inorg. Chem., 2000, 39, 447-457.

48 T. J. Wadas, R. J. Lachiotte and R. Eisenberg, Inorg. Chem., 2003, 42, 3772-3778.

49 K.-Y. Kim, S. Liu, M. E. Köse and K. S. Schanze, Inorg. Chem., 2006, 45, 2509-2519.

50 F. N. Castellano, I. E. Pomestchenko, E. Shikhova, F. Hua, M. L. Muro and N. Rajapakse, Coord. Chem. Rev., 2006, 250, 1819-1828.

51 C.-H. Tao and V. W.-W. Yam, J. Photochem. Photobiol., C, 2009, 10, 130-140.

52 R. Saha, M. A. Qaium, D. Debnath, M. Younus, N. Chawdhury, N. Sultana, G. Kociok-Kohn, L.-l. Ooi, P. R. Raithby and M. Kijima, Dalton Trans., 2005, 27602765, DOI: 10.1039/b505484b.

53 W. Wu, J. Zhao, J. Sun, L. Huang and X. Yi, J. Mater. Chem. C, 2013, 1, 705-716.

54 I. Fratoddi, C. Battocchio, A. Furlani, P. Mataloni, G. Polzonetti and M. V. Russo, J. Organomet. Chem., 2003, 674, 10-23.

55 K. Gagnon, S. M. Aly, A. Brisach-Wittmeyer, D. Bellows, F.-F. Bérubé, L. Caron, A. S. Abd-El-Aziz, D. Fortin and P. D. Harvey, Organometallics, 2008, 27, 2201-2214.

56 L. Liu, D. Fortin and P. D. Harvey, Inorg. Chem., 2009, 48, 5891-5900.

57 D. Bellows, S. M. Aly, C. P. Gros, M. El Ojaimi, J.-M. Barbe, R. Guilard and P. D. Harvey, Inorg. Chem., 2009, 48, 76137629.

58 M. S. Khan, M. R. A. A. Al-Mandhary, M. K. Al-Suti, F. R. Al-Battashi, S. Al-Saadi, B. Ahrens, J. K. Bjernemose, M. F. Mahon, P. R. Raithby, M. Younus, N. Chawdhury, A. Köhler, E. A. Marseglia, E. Tedesco, N. Feeder and S. J. Teat, Dalton Trans., 2004, 2377-2385.

59 N. J. Long, C. K. Wong and A. J. P. White, Organometallics, 2006, 25, 2525-2532.

60 L. Liu, W.-W. Wong, J.-X. Shi, K.-W. Cheah, T.-H. Lee and L. M. Leung, J. Organomet. Chem., 2006, 691, 40284041.

61 D. Fortin, S. Clément, K. Gagnon, J.-F. Bérubé, M. P. Stewart, W. E. Geiger and P. D. Harvey, Inorg. Chem., 2009, 48, 446-454.

62 J. M. Keller, K. D. Glusac, E. O. Danilov, S. McIlroy, P. Sreearuothai, A. R. Cook, H. Jiang, J. R. Miller and K. S. Schanze, J. Am. Chem. Soc., 2011, 133, 11289-11298.

63 J. R. Berenguer, E. Lalinde and M. Teresa Moreno, Coord. Chem. Rev., 2010, 254, 832-875.

64 J. E. Rogers, J. E. Slagle, D. M. Krein, A. R. Burke, B. C. Hall, A. Fratini, D. G. McLean, P. A. Fleitz, T. M. Cooper, M. Drobizhev, N. S. Makarov, A. Rebane, K.-Y. Kim, R. Farley and K. S. Schanze, Inorg. Chem., 2007, 46, 6483-6494.

65 A. A. Rachford, S. Goeb and F. N. Castellano, J. Am. Chem. Soc., 2008, 130, 2766-2767.
66 L. Liu, D. Huang, S. M. Draper, X. Yi, W. Wu and J. Zhao, Dalton Trans., 2013, 42, 10694-10706.

67 H. Guo, M. L. Muro-Small, S. Ji, J. Zhao and F. N. Castellano, Inorg. Chem., 2010, 49, 6802-6804.

68 M.-H. Nguyen and J. H. K. Yip, Organometallics, 2012, 31, 7522-7531.

69 M.-H. Nguyen, V. H. Nguyen and J. H. K. Yip, Organometallics, 2013, 32, 7283-7291.

70 D. N. Kozhevnikov, V. N. Kozhevnikov, M. Z. Shafikov, A. M. Prokhorov, D. W. Bruce and J. A. Gareth Williams, Inorg. Chem., 2011, 50, 3804-3815.

71 Y. Liu, H. Guo and J. Zhao, Chem. Commun., 2011, 47, 11471-11473.

72 Y. Y. Chia and M. G. Tay, Dalton Trans., 2014, 43, 1315913168.

73 J. Hu, R. Lin, J. H. K. Yip, K.-Y. Wong, D.-L. Ma and J. J. Vittal, Organometallics, 2007, 26, 65336543.

74 A. Singh and P. R. Sharp, J. Am. Chem. Soc., 2006, 128, 5998-5999.

75 H. B. Lee and P. R. Sharp, Organometallics, 2005, 24, 4875-4877.

76 S. Lentijo, G. Aullon, J. A. Miguel and P. Espinet, Dalton Trans., 2013, 42, 6353-6365.

77 M.-H. Nguyen and J. H. K. Yip, Organometallics, 2010, 29, 2422-2429.

78 W. Y. Heng, J. Hu and J. H. K. Yip, Organometallics, 2007, 26, 6760-6768.

79 B.-Y. Wang, A. R. Karikachery, Y. Li, A. Singh, H. B. Lee, W. Sun and P. R. Sharp, J. Am. Chem. Soc., 2009, 131, 3150-3151.

80 S. Lentijo, J. A. Miguel and P. Espinet, Inorg. Chem., 2010, 49, 9169-9177.

81 W. G. Herkstroeter, A. A. Lamola and G. S. Hammond, J. Am. Chem. Soc., 1964, 86, 4537-4540.

82 D. E. Damschen, C. D. Merritt, D. L. Perry, G. W. Scott and L. D. Talley, J. Phys. Chem., 1978, 82, 2268-2272.

83 R. W. Anderson Jr., R. M. Hochstrasser, H. Lutz and G. W. Scott, Chem. Phys. Lett., 1974, 28, 153-157.

84 R. M. Hochstrasser, H. Lutz and G. W. Scott, Chem. Phys. Lett., 1974, 24, 162-167.

85 D. Wöll, J. Smirnova, W. Pfleiderer and U. E. Steiner, Angew. Chem., Int. Ed., 2006, 45, 2975-2978.

86 D. Wöll, S. Laimgruber, M. Galetskaya, J. Smirnova, W. Pfleiderer, B. Heinz, P. Gilch and U. E. Steiner, J. Am. Chem. Soc., 2007, 129, 12148-12158.

87 G. Amirzadeh and W. Schnabel, Makromol. Chem., 1981, 182, 2821-2835.

88 M. G. Neumann, M. H. Gehlen, M. V. Encinas, N. S. Allen, T. Corrales, C. Peinado and F. Catalina, J. Chem. Soc., Faraday Trans., 1997, 93, 1517-1521.

89 M. Aydin, N. Arsu, Y. Yagci, S. Jockusch and N. J. Turro, Macromolecules, 2005, 38, 4133-4138.

90 L. Cokbaglan, N. Arsu, Y. Yagci, S. Jockusch and N. J. Turro, Macromolecules, 2003, 36, 2649-2653. 
91 T. Corrales, C. Peinado, F. Catalina, M. G. Neumann, N. S. Allen, A. M. Rufs and M. V. Encinas, Polymer, 2000, 41, 9103-9109.

92 X. Jiang and J. Yin, Macromol. Chem. Phys., 2008, 209, 1593-1600.

93 H. Tar, D. Sevinc Esen, M. Aydin, C. Ley, N. Arsu and X. Allonas, Macromolecules, 2013, 46, 3266-3272.

94 J. C. Dalton and F. C. Montgomery, J. Am. Chem. Soc., 1974, 96, 6230-6232.

95 C. Ley, F. Morlet-Savary, P. Jacques and J. P. Fouassier, Chem. Phys., 2000, 255, 335-346.

96 T.-i. Lai and E. C. Lim, Chem. Phys. Lett., 1980, 73, 244248.

97 X. Allonas, C. Ley, C. Bibaut, P. Jacques and J. P. Fouassier, Chem. Phys. Lett., 2000, 322, 483-490.

98 P. K. Monaghan and R. J. Puddephatt, Organometallics, 1985, 4, 1406-1412.

99 A. Abo-Amer, M. S. McCready, F. Zhang and R. J. Puddephatt, Can. J. Chem., 2011, 90, 46-54.

100 G. W. Parshall, J. Am. Chem. Soc., 1966, 88, 704-708.

101 A. Pidcock, R. E. Richards and L. M. Venanzi, J. Chem. Soc. A, 1966, 1707-1710, DOI: 10.1039/J19660001707.

102 J. A. Pople and D. P. Santry, Mol. Phys., 1964, 8, 1-18.

103 T. Sajoto, P. I. Djurovich, A. Tamayo, M. Yousufuddin, R. Bau, M. E. Thompson, R. J. Holmes and S. R. Forrest, Inorg. Chem., 2005, 44, 7992-8003.

104 S. K. Doorn, R. B. Dyer, P. O. Stoutland and W. H. Woodruff, J. Am. Chem. Soc., 1993, 115, 6398-6405.

105 D. Burget and P. Jacques, J. Lumin., 1992, 54, 177-181.

106 D. W. Wöll, PhD Dissertation, University of Konstanz, 2006.

107 T. Yoshida, T. Matsuda, S. Otsuka, G. W. Parshall and W. G. Peet, in Inorganic Syntheses, John Wiley \& Sons, Inc., 2007, ch. 32, pp. 122-123, DOI: 10.1002/9780470132593.

108 G. M. Sheldrick, SHELXL-97, Program for Crystal Structure Solution and Refinement, Universität Göttingen, 1997.

109 L. J. Farrugia, J. Appl. Crystallogr., 2013, 45, 849-854.

110 M. J. Frisch, G. Trucks, H. B. Schlegel, G. E. Scuseria, M. A. Robb, J. R. Cheeseman, G. Scalmani, V. Barone, B. Mennucci, G. A. Petersson, H. Nakatsuji, M. Caricato, X. Li, H. P. Hratchian, A. F. Izmaylov, J. Blonio, G. Zheng, J. L. Sonnenberg, M. Hada, M. Ehara, K. Toyota,
R. Fukuda, J. Hasegawa, M. Ishida, T. Nakajima, Y. Honda, O. Kitao, H. Nakai, T. Vreven, J. A. Montgomery Jr., J. E. Peralta, F. Ogliaro, M. Bearpark, J. J. Heyd, E. Brothers, K. N. Kudin, V. N. Staroverov, R. Kobayashi, J. Normand, K. Raghavachari, A. Rendell, J. C. Burant, S. S. Iyengar, J. Tomasi, M. Cossi, N. Rega, J. M. Millam, M. Klene, J. E. Knox, J. B. Cross, V. Bakken, C. Adamo, J. Jaramillo, R. Gomperts, R. E. Stratmann, O. Yazyev, A. J. Austin, R. Cammi, C. Pomelli, J. W. Ochterski, R. L. Martin, K. Morokuma, V. G. Zakrzewski, G. A. Voth, P. Salvador, J. J. Dannenberg, S. Dapprich, A. D. Daniels, Ö. Farkas, J. B. Foresman, J. V. Ortiz, J. Cioslowski and D. J. Fox, Gaussian09, Version 8.0, Gaussian Inc., Wallingford CT, 2009.

111 O. Gunnarsson and B. I. Lundqvist, Phys. Rev. B: Solid State, 1976, 13, 4274.

112 W. Küchle, M. Dolg, H. Stoll and H. Preuss, J. Chem. Phys., 1994, 100, 7535-7532.

113 M. Dolg, H. Stoll and H. Preuss, J. Chem. Phys., 1989, 90, 1730-1734.

114 D. Andrae, U. Haeussermann, M. Dolg, H. Stoll and H. Preuss, Theor. Chim. Acta, 1990, 77, 123.

115 P. H. Hariharan and J. A. Pople, Theor. Chim. Acta, 1973, 28, 213-222.

116 J. P. Perdew, K. Burke and M. Enzerhof, Phys. Rev. Lett., 1996, 77, 3865-3868.

117 C. Adamo and V. Barone, J. Chem. Phys., 1999, 110, 61586170.

118 E. Cancés, B. Menucci and J. Tomasi, J. Chem. Phys., 1997, 107, 3032-3041.

119 B. Mennucci and J. Tomasi, J. Chem. Phys., 1997, 106, 5151-5158.

120 M. Cossi, N. Rega, G. Scalmani and V. Barone, J. Comput. Chem., 2003, 24, 669-681.

121 G. Scalamani and M. J. Frisch, J. Chem. Phys., 2010, 132, 114110-114124.

122 E. Runge and K. U. G. E, Phys. Rev. Lett., 1984, 52, 9971000.

123 N. M. O'Boyle, A. L. Tenderholt and K. M. Langner, J. Comput. Chem., 2008, 29, 839-845.

124 T. Keith and J. Millam, GaussView, Version 3, Semichem Inc., Shawnee Mission KS, 2009. 